\title{
ARTICLE
}

\section{Reproductive activity of swordfish Xiphias gladius, in the Atlantic Ocean inferred on the basis of macroscopic indicators}

\author{
Actividad reproductiva del pez espada Xiphias gladius, en el Océano Atlántico \\ deducida en base a indicadores macroscópicos
}

\section{Jaime Mejuto $^{1}$ and Blanca García-Cortés ${ }^{1}$}

\author{
'Instituto Español de Oceanografía, P.O. Box. 130, 15080 A Coruña, España. jaime.mejuto@co.ieo.es
}

\begin{abstract}
Resumen.- A partir del análisis del índice gonadal de 18.279 hembras de pez espada, se caracterizaron regiones con intensos procesos de maduración-reproducción frente a otras con procesos reproductivos menos frecuentes, esporádicos e inexistentes. Las hembras mayores de $145 \mathrm{~cm}$ mandíbula inferior-horquilla (LJFL) pueden presentar índices gonadales altos o bajos según la región y la estación del año. Índices gonadales elevados fueron generalmente detectados en áreas con Temperatura Superficial de Mar (TSM) dentro del rango $24^{\circ}-29^{\circ} \mathrm{C}$. Sin embargo, esta actividad reproductiva en las hembras parece estar relacionada con la temperatura existente en las capas epipelágicas y generalmente restringida a las regiones cálidas del Atlántico occidental con termoclina profunda. La talla de primera madurez de las hembras (LJFL ${ }_{50}$ ) fue estimada en $146,5 \mathrm{~cm}$ LJFL y la función de madurez definida como $\mathrm{p}_{\mathrm{m}}=1 /\left(1+\mathrm{e}^{(-0,1398(\mathrm{LFL}-146,5))}\right)$. Indicadores cualitativos del estado de madurez de las hembras apoyan los resultados obtenidos mediante índices gonadales. Los datos de tasas de captura por talla, sexo y región señalan a los machos entre 125 y $165 \mathrm{~cm}$ LJFL como los causantes de la elevada prevalencia de machos en las regiones con más intensos procesos reproductivos. Los característicos patrones de proporción de sexos por talla del tipo 'desove' son explicados por esta anomalía positiva en estas regiones a favor de los machos en una proporción que puede alcanzar sobre 9 ó 11 veces la abundancia de las hembras dentro de ese mismo rango de tallas intermedias. El complejo proceso reproductivo de esta especie apunta a la existencia de rituales de cortejo que explicarían su patrón migratorio y la estratificación según talla-sexo-área.
\end{abstract}

Palabras clave: Pez espada, reproducción, índice gonadal, estados de madurez

Abstract.- Regions with intense maturation-reproduction processes versus other regions showing less frequent, sporadic and non-existent maturation events were characterized on the basis of the gonadal index of 18,279 female swordfish. Females larger than $145 \mathrm{~cm}$ lower jaw-fork length (LJFL) may present high or low gonadal index values depending on the region and season. The highest gonadal indices were observed mostly in areas having Sea Surface Temperature (SST) ranging between $24^{\circ}-29^{\circ} \mathrm{C}$. However, the reproductive activity of females appears to be mainly restricted to the warmer epipelagic layers of the western regions with a deeper thermocline. The size at first maturity of females (LJFL $L_{50}$ ) was estimated at $146.5 \mathrm{~cm}$ LJFL and the maturity function was $p_{m}=1 /\left(1+\mathrm{e}^{(-0.1398(\mathrm{LFL}-146.5))}\right)$. Qualitative maturity indicators of females support the results obtained using gonadal indices. According to catch rate data by size, sex and region, the presence of males 125 $165 \mathrm{~cm}$ LJFL would account for the high prevalence of males in regions where the most intense reproductive processes were observed. The characteristic 'spawning' related sex-ratio at size patterns are explained by this positive anomaly in these regions favouring males in a ratio up to 9 or 11 times greater than the abundance of females within the same medium size range. The complex reproductive process of this species would point to the practice of courting rituals, which would explain the migratory pattern of this species and its stratification by area-size-sex.

Key words: Swordfish, reproduction, gonadal index, maturity stages

\section{INTRODUCTION}

The swordfish (Xiphias gladius Linnaeus, 1758) is a gonochoric species that reproduces by external fertilization (Palko et al. 1981). The gonads are paired organs located ventrally on either side of the intestinal sac and the large natatory bladder in the anterior anal area. The reproductive activity of females has been described for specific regions, pointing to the existence of multiple batch spawning on the basis of the sequential development of the different types of oocytes which are produced during a period of intense gonad development under suitable environmental conditions (Arocha 1997). Although the swordfish is a solitary species, rarely 
forming schools per se, there have been some descriptions from fishermen and scientists reporting 'coupling' behavior indicating that they may 'pair up' for reproductive purposes (Goode 1883, Palko et al. 1981).

Studies of the reproductive processes of swordfish are more difficult to conduct than on most teleosts, owing to their highly migratory oceanic behavior, their wide geographic distribution -mainly between $50^{\circ} \mathrm{N}$ and $50^{\circ} \mathrm{S}-$ and their body size. The historical oceanic Atlantic swordfish fisheries began to develop in the middle of the past century in temperate regions, particularly in areas where reproductive processes are not usually observed (Becket 1974). However some reproductive events were described several decades ago around Cuba (GuitartManday 1964). In recent decades the geographic expansion of the fleets headed for the warm waters of the tropical and subtropical zones, beginning in the 1980s, has helped broaden our knowledge of the reproductive biology of this species. Most of the information regarding the reproduction of the Atlantic swordfish is relatively recent and largely originates from the northwestern regions (i.e., Guitart-Manday 1964, Palko et al. 1981, Taylor \& Murphy 1992, Arocha et al. 1994, Arocha \& Lee 1995, 1996; Arocha 1997, 2002, 2007; Mejuto \& García-Cortés 2003a). One of the most comprehensive papers on these western regions focusing chiefly on histological studies (Arocha 1997) detected spawning areas-times in the subtropical regions of the north-west (NW) Atlantic as far as $35^{\circ} \mathrm{N}$. The first study encompassing a broad spatial coverage conducted in the north-east (NE) Atlantic highlighted the lack of maturation and reproductive processes between $35^{\circ}-45^{\circ} \mathrm{N}$ and $10^{\circ}-40^{\circ} \mathrm{W}$, on the basis of microscopic data and gonadal indices, and identified the systematic difference in weight and the biometric relationship between female gonads and provided fertility estimations and other reproductive variables (García \& Mejuto 1988). In the South Atlantic, the indicators of swordfish reproduction were described by Brazilian researchers between $20^{\circ}-33^{\circ} \mathrm{S}$ and $40^{\circ}-50^{\circ} \mathrm{W}$ (Amorin \& Arfelli 1984). Later studies broadened our knowledge on reproduction in these oceanic areas (Mejuto \& GarcíaCortés 1997, Hazin et al. 2001, Mejuto \& García-Cortés 2003a). Part of the background on the reproduction of the Atlantic swordfish has recently been summarized (Neilson et al. 2013). The Pacific swordfish has also been studied in terms of its developmental processes for reproduction (i.e., Kume \& Joseph 1969, Matsumoto \& Kazama 1974, Nishikawa \& Ueyanagi 1974, Nishikawa et al. 1978, 1985; Miyabe \& Bayliff 1987, Nakano \& Bayliff 1992, Hinton et al. 1997, DeMartini et al. 2000, Young et al. 2003, Mejuto et al. 2008), while other studies have reported on the absence of said processes (Weber \& Goldberg 1986, Ramon \& Castro-Longoria 1994). In the Indian Ocean, studies on the reproductive processes of this species have only been carried out recently (Mejuto et al. 1994, 1995, 2006; Mejuto \& García-Cortés 2003a, Poisson \& Taquet 2000, Poisson et al. 2001, García-Cortés \& Mejuto 2003, Poisson \& Fauvel 2009a, b, Varghese et al. 2013).

Most of the aforementioned studies on reproduction of the swordfish were based on samples obtained from relatively limited areas-seasons. Their results have been the basis for several hypotheses on the reproductive behavior of the species. It has been frequently assumed that, in addition to the intrinsic requirements of each individual, swordfish reproduction requires the simple occurrence of certain environmental conditions regarding sea surface temperature.

This work focuses on a reproductive study of the swordfish in broader areas of the north and south Atlantic which were accessible to the Spanish surface longline commercial fleet, using macroscopic-quantitative indices, in addition to macroscopic-qualitative indicators. All of the above will help to improve the definition of the maturation and spawning areas-times of this species in the Atlantic Ocean, thus explaining this species' reproductive behavior as a more complex process than previously described, with impact on the population structure (Neilson et al. 2013). The work also leads to the design of further studies based on microscopic analyses from selected areas.

\section{Materials AND METHODS}

The data were obtained on board commercial Spanish surface longliners during the period 1995-2003. Catch data by sex, fishing effort (in number of hooks set) and biological data of the swordfish caught were collected on a total of 40,848 swordfish specimens of which 18,279 females were analyzed in terms of their reproduction parameters. The observations were classified by regions as previously defined for studies on sex-ratios at size (Mejuto et al. 1998, Mejuto 2007), (Fig. 1). The lower jawfork length (LJFL) was measured to the lowest centimeter and grouped into $5 \mathrm{~cm}$ size classes adjusted to their lower limit (Miyake 1990). The maturity of the females was observed during the dissection of the swordfish on board. The gonads were weighed with an accuracy of $\pm 15 \mathrm{~g}$. The maturity stage was established by means of 


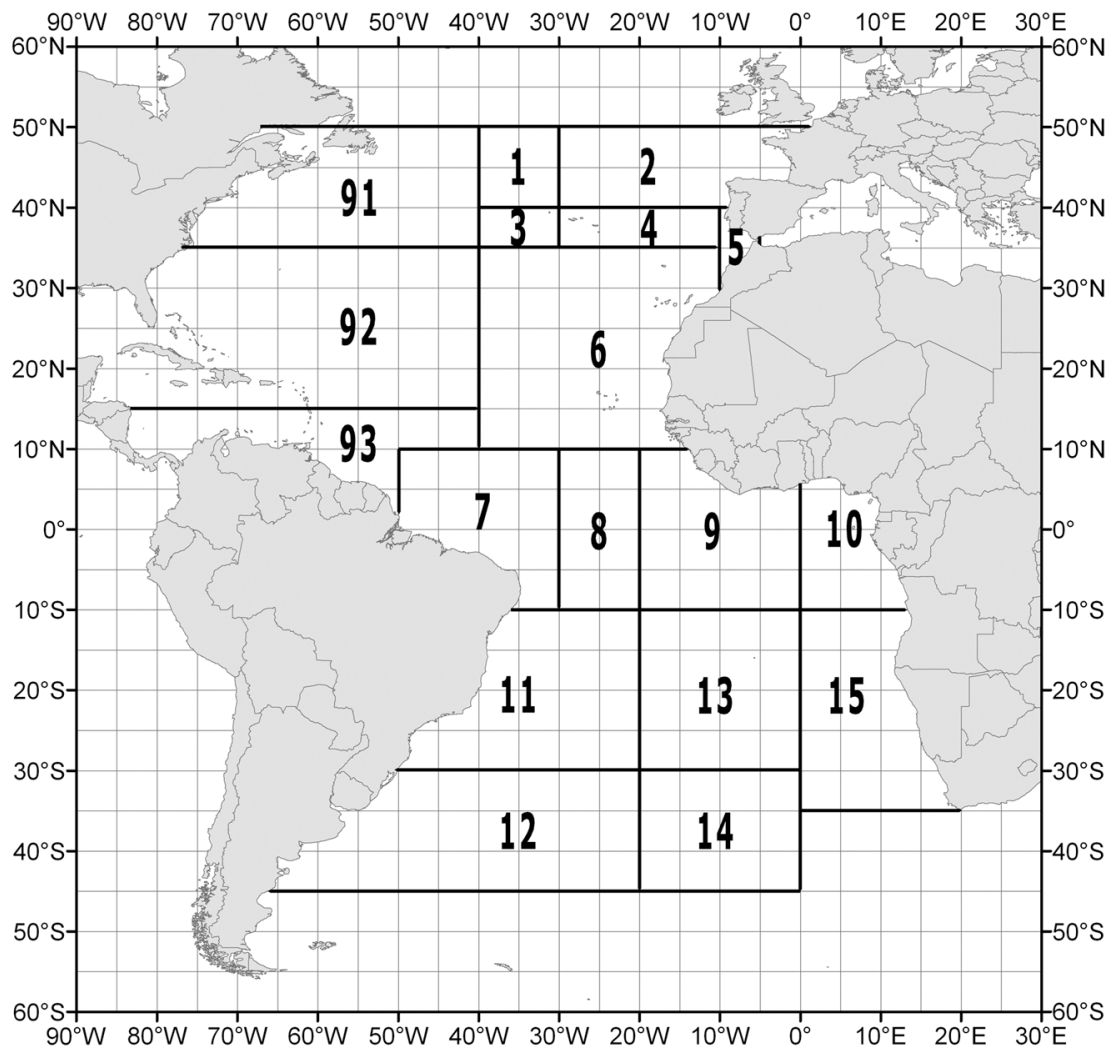

Figure 1. Definition of the regions used in the analyses / Definición de las regiones usadas en los análisis

quantitative and qualitative macroscopic indicators. The quantitative maturity index of each female sampled, the so called gonadal index (IG1), was defined for females: $\mathrm{IG} 1=\left(\mathrm{Wg} / \mathrm{LJFL}^{3}\right) * 10^{4}$, modified from the equation used for this species (Kume \& Joseph 1969): $\mathrm{Wg}=$ weight of the two female gonads, in grams. LJFL $=$ standard length from the lower jaw to the fork in $\mathrm{cm}$.

The IG1 values were mapped into $5^{\circ} \times 5^{\circ}$ squares for two different size ranges (all size ranges $50 \leq \mathrm{LJFL} \leq 350$ and restricted to $\mathrm{LJFL} \geq 150 \mathrm{~cm}$ ) and the observations obtained in each $5^{\circ} \times 5^{\circ}$ area were classified into 3 ranges: no significant reproductive processes or gonad resting stage $(0<$ IG1 < 2.09), maturation-reproductive activity $(2.09 \leq \mathrm{IG} 1<5)$ and extreme maturation-reproductive activity (IG1 $\geq 5$ ). The IG1 values (maximum, minimum, mean and their $95 \%$ confidence intervals) were obtained by region and size class $(50 \leq \mathrm{LJFL} \leq 350)$. Analyses were also carried out on the IG1 by means of box-plots (S-Plus, MathSoft 1997) for sizes LJFL > $145 \mathrm{~cm}$ and by monthly periods in each region to detect monthly patterns. This threshold was selected based on preliminary descriptive analyses. A comparison among all these values could be very helpful in the identification of the regions that are highly likely to present maturation or spawning processes versus regions where this kind of activity may be only sporadic or non-existent. The IG1 values pertaining to each female were compared with the mean seawater surface temperature (SSTm) observed during the fishing set in which the female was captured, averaging the SSTs recorded in the initial and final position of the set. The IG1 values were also plotted in the descriptive analyses with the LJFL size classes. The size at first maturity of females $\left(\mathrm{LJFL}_{50}\right)$ was calculated on the basis of the ratio of females identified as mature in each size class using observations obtained in regions with the consistently highest reproductive patterns throughout the year. A linear model was fitted to the paired values LJFL and Ln [(1 / \% mature)-1] to define the parameters of the maturity ogive. The observations starting from the smallest sizes were fitted until the $\mathrm{LJFL}_{50}$ value was reached. The 
probability of maturity for a given female size was expressed by: $\left.p_{\mathrm{m}}=1 /\left(1-\mathrm{e}^{\left(-\mathrm{a}\left(\mathrm{LJFL}_{\mathrm{LJFL}}\right)\right.}{ }_{50}\right)\right),($ Sparre \& Venema 1997). A sensitivity analysis was also carried out using all the paired values.

Catch per unit of effort by sex, in number (CPUEn) and in weight (CPUEw) per thousand hooks, was calculated for each region. The CPUEn was divided into 4 size groups labelled L1, L2, L3 and L4, respectively: ( $50 \leq$ LJFL < 125), $(125 \leq \mathrm{LJFL}<170),(170 \leq \mathrm{LJFL}<205)$ and $(205 \leq \mathrm{LJFL} \leq$ $350)$. The first group defined individuals of the two sexes in the most juvenile stage, with a similar ratio being expected between males and females. The second defined the juvenile females and most males in a potentially reproductive size. The third was designed to define the potential female breeders and the small number of large males. The fourth singled out, almost exclusively or with the greatest probability, the largest females. The CPUE ratios (R_CPUE) between males (M) and females (F) and the anomalies found in terms of the presence of each sex (Anomaly R_CPUEn) for each region were defined: R_CPUE $=$ (CPUE males / CPUE females), and the Anomaly R_CPUE $=($ R_CPUE -1$)$.

A qualitative index of the maturity stage called the 'gonadal stage' was also established only for females in 6 levels on the basis of visual criteria: 1: 'primordial', 2: 'developing', 3: 'developed, hydrated with visible opaque oocytes', 4: 'very developed, oocytes of around $1 \mathrm{~mm}$, transparent', 5: 'evident-spontaneous spawning at the time of capture', 6: 'post-spawning, flaccid, bloody gonads, visible interior lumen, post-spawning residues'.

\section{RESULTS}

A total of 18,279 female swordfish were analyzed to obtain their gonadal indices. A large number of observations were available in most of the regions (Table 1). The broad size range covered by the samples accurately represents the sizes regularly captured by the oceanic surface longline fleets, ranging from juvenile females to large adult female specimens (Fig. 2). The geographic coverage of the observations corresponds to most of the distribution areas of Atlantic swordfish where the most intense fishing activity takes place, except for the NW Atlantic areas because the Spanish fleet has historically had very little or null access to these areas (Fig. 3). Descriptive analyses of IG1 show the relationship between female size and the mean seawater surface temperature with the IG1 values (Fig. 4). The IG1 values have a high probability of being less than 2.0 in the case of females smaller than $150 \mathrm{~cm}$ size class. Females larger than these size classes may present IG1 values that are either lower than this value as in most of the observations- or higher than said value. On the other hand, females around or greater than $150 \mathrm{~cm}$ often have high gonadal indices, especially within the $24^{\circ}-29^{\circ} \mathrm{C}$ range, suggesting that the maturation of the

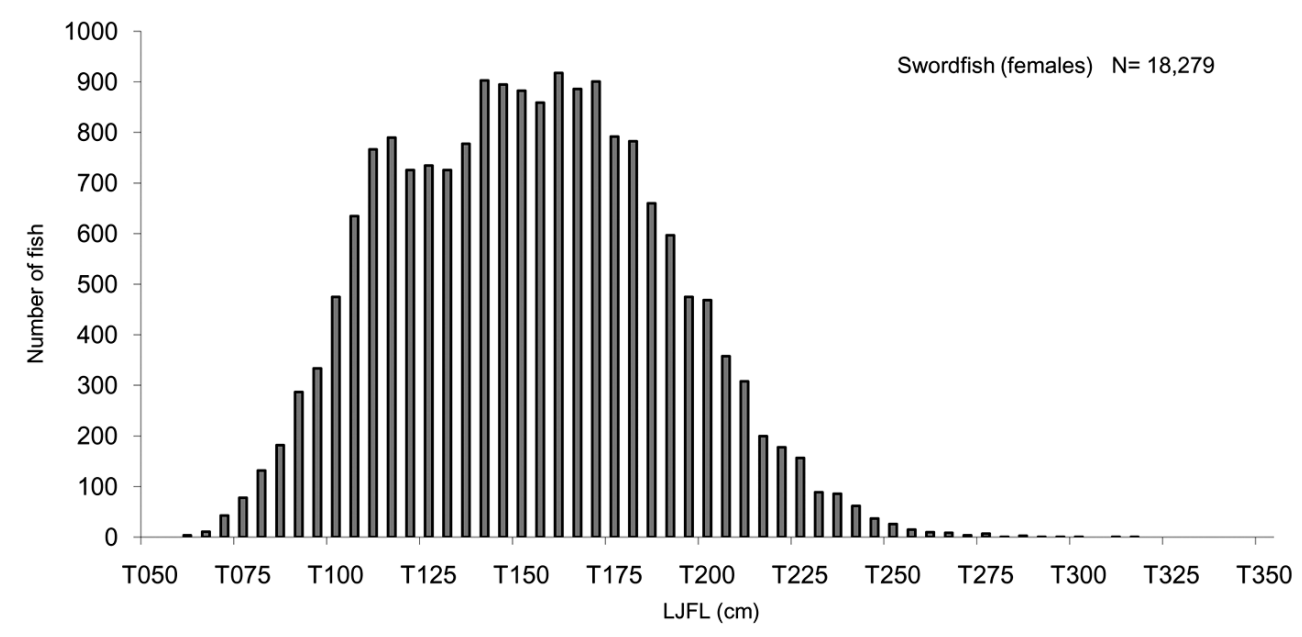

Figure 2. Histogram of the frequency (number of fish) of swordfish females examined to obtain the gonadal index, by size class (LJFL) and for all the regions combined / Histograma de frecuencia (número) de peces espada hembra examinadas para obtener índices gonadales, por clase de talla (LJFL) y para todas las regiones combinadas 
Table 1. Number of females observed for the analyses of gonadal indices, by $5 \mathrm{~cm}$ size class (LJFL $\mathrm{cm}$ ), by region (R) and the total combined / Número de hembras observadas para los análisis de índices gonadales, por clase de talla de $5 \mathrm{~cm}$ (LJFL cm), por región $(R)$ y total combinado

\begin{tabular}{llllllllllllllllll}
\hline LJFL cm & R01 & R02 & R03 & R04 & R06 & R07 & R08 & R09 & R10 & R11 & R12 & R13 & R15 & R91 & R92 & R93 & Total
\end{tabular} $\begin{array}{llllllllllllllllll}050 & 0 & 0 & 0 & 0 & 0 & 0 & 0 & 0 & 0 & 0 & 0 & 0 & 0 & 0 & 0 & 0 & 0\end{array}$ $\begin{array}{llllllllllllllllll}055 & 0 & 0 & 0 & 0 & 0 & 0 & 0 & 0 & 0 & 0 & 0 & 0 & 0 & 0 & 0 & 0 & 0\end{array}$ $\begin{array}{llllllllllllllllll}060 & 0 & 0 & 0 & 0 & 0 & 0 & 1 & 0 & 0 & 3 & 0 & 0 & 0 & 0 & 0 & 0 & 4\end{array}$ $\begin{array}{llllllllllllllllll}065 & 0 & 0 & 0 & 0 & 3 & 0 & 0 & 4 & 0 & 3 & 0 & 1 & 0 & 0 & 0 & 0 & 11\end{array}$ $\begin{array}{llllllllllllllllll}070 & 0 & 0 & 0 & 1 & 10 & 0 & 2 & 19 & 3 & 5 & 0 & 1 & 0 & 2 & 0 & 0 & 43\end{array}$ $\begin{array}{llllllllllllllllll}075 & 0 & 0 & 0 & 0 & 7 & 2 & 5 & 37 & 7 & 5 & 0 & 1 & 0 & 13 & 1 & 0 & 78\end{array}$ $\begin{array}{llllllllllllllllll}080 & 0 & 1 & 1 & 3 & 5 & 6 & 4 & 60 & 23 & 5 & 0 & 3 & 4 & 15 & 2 & 0 & 132\end{array}$ $\begin{array}{llllllllllllllllll}085 & 0 & 6 & 4 & 6 & 6 & 3 & 10 & 67 & 32 & 6 & 0 & 11 & 2 & 28 & 1 & 0 & 182\end{array}$ $\begin{array}{llllllllllllllllll}090 & 2 & 1 & 30 & 4 & 15 & 12 & 13 & 66 & 69 & 11 & 0 & 6 & 1 & 53 & 0 & 4 & 287\end{array}$ $\begin{array}{llllllllllllllllll}095 & 2 & 2 & 38 & 6 & 29 & 9 & 11 & 91 & 63 & 19 & 0 & 6 & 2 & 48 & 0 & 8 & 334\end{array}$ $\begin{array}{llllllllllllllllll}100 & 6 & 4 & 36 & 2 & 37 & 19 & 11 & 140 & 99 & 12 & 1 & 5 & 8 & 60 & 3 & 32 & 475\end{array}$ $\begin{array}{llllllllllllllllll}105 & 5 & 11 & 43 & 2 & 66 & 12 & 28 & 167 & 172 & 14 & 1 & 8 & 11 & 49 & 0 & 46 & 635\end{array}$

$\begin{array}{llllllllllllllllll}110 & 3 & 7 & 57 & 3 & 69 & 6 & 26 & 220 & 234 & 22 & 0 & 12 & 11 & 45 & 1 & 51 & 767\end{array}$

$\begin{array}{llllllllllllllllll}115 & 6 & 25 & 49 & 3 & 72 & 13 & 24 & 178 & 227 & 48 & 2 & 20 & 8 & 61 & 1 & 53 & 790\end{array}$

$\begin{array}{llllllllllllllllll}120 & 2 & 14 & 65 & 3 & 61 & 5 & 24 & 158 & 192 & 38 & 4 & 22 & 7 & 77 & 2 & 52 & 726\end{array}$

$\begin{array}{llllllllllllllllll}125 & 5 & 21 & 66 & 5 & 61 & 5 & 12 & 156 & 172 & 64 & 6 & 37 & 5 & 68 & 0 & 52 & 735\end{array}$

$\begin{array}{llllllllllllllllll}130 & 2 & 19 & 87 & 3 & 74 & 3 & 15 & 132 & 166 & 78 & 6 & 23 & 2 & 74 & 1 & 41 & 726\end{array}$

$\begin{array}{llllllllllllllllll}135 & 2 & 20 & 78 & 4 & 73 & 2 & 13 & 152 & 225 & 65 & 6 & 34 & 2 & 64 & 1 & 37 & 778\end{array}$

$\begin{array}{llllllllllllllllll}140 & 1 & 19 & 83 & 1 & 93 & 9 & 8 & 201 & 269 & 71 & 11 & 30 & 7 & 55 & 0 & 45 & 903\end{array}$

$\begin{array}{llllllllllllllllll}145 & 0 & 25 & 81 & 0 & 81 & 6 & 17 & 209 & 288 & 78 & 6 & 29 & 4 & 45 & 0 & 26 & 895\end{array}$

$\begin{array}{llllllllllllllllll}150 & 0 & 13 & 67 & 0 & 67 & 12 & 20 & 177 & 310 & 106 & 12 & 21 & 6 & 40 & 1 & 31 & 883\end{array}$

$\begin{array}{llllllllllllllllll}155 & 1 & 19 & 46 & 0 & 52 & 12 & 33 & 242 & 252 & 88 & 18 & 18 & 3 & 29 & 1 & 45 & 859\end{array}$

$\begin{array}{llllllllllllllllll}160 & 1 & 10 & 38 & 0 & 56 & 10 & 23 & 259 & 284 & 126 & 11 & 28 & 5 & 38 & 1 & 28 & 918\end{array}$

$\begin{array}{llllllllllllllllll}165 & 2 & 12 & 28 & 0 & 49 & 14 & 37 & 221 & 290 & 118 & 7 & 37 & 4 & 37 & 0 & 30 & 886\end{array}$

$\begin{array}{llllllllllllllllll}170 & 2 & 7 & 27 & 0 & 33 & 15 & 41 & 234 & 284 & 150 & 13 & 51 & 1 & 23 & 0 & 20 & 901\end{array}$

$\begin{array}{llllllllllllllllll}175 & 0 & 4 & 24 & 0 & 38 & 8 & 30 & 211 & 220 & 151 & 11 & 66 & 3 & 11 & 1 & 14 & 792\end{array}$

$\begin{array}{llllllllllllllllll}180 & 0 & 4 & 25 & 0 & 24 & 20 & 33 & 219 & 183 & 165 & 11 & 65 & 3 & 13 & 1 & 17 & 783\end{array}$

$\begin{array}{llllllllllllllllll}185 & 2 & 5 & 18 & 0 & 23 & 8 & 28 & 196 & 139 & 152 & 9 & 62 & 1 & 10 & 0 & 7 & 660\end{array}$

$\begin{array}{llllllllllllllllll}190 & 1 & 6 & 21 & 0 & 14 & 7 & 30 & 160 & 129 & 145 & 8 & 58 & 1 & 12 & 0 & 5 & 597\end{array}$

$\begin{array}{llllllllllllllllll}195 & 0 & 0 & 11 & 0 & 17 & 9 & 20 & 108 & 100 & 124 & 10 & 64 & 0 & 6 & 0 & 6 & 475\end{array}$

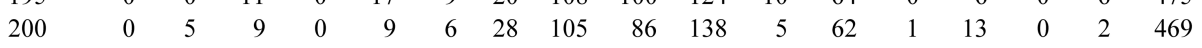

$\begin{array}{llllllllllllllllll}205 & 0 & 4 & 18 & 0 & 5 & 4 & 18 & 77 & 56 & 99 & 4 & 63 & 0 & 3 & 0 & 7 & 358\end{array}$

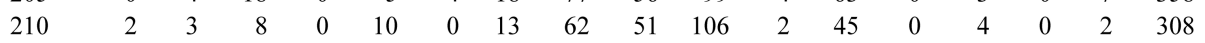

$\begin{array}{llllllllllllllllll}215 & 1 & 4 & 6 & 0 & 3 & 1 & 8 & 45 & 28 & 62 & 1 & 37 & 1 & 2 & 0 & 1 & 200\end{array}$

$\begin{array}{llllllllllllllllll}220 & 0 & 2 & 2 & 0 & 4 & 7 & 13 & 32 & 18 & 65 & 2 & 28 & 0 & 2 & 0 & 3 & 178\end{array}$

$\begin{array}{llllllllllllllllll}225 & 0 & 5 & 4 & 0 & 2 & 3 & 7 & 31 & 21 & 61 & 3 & 18 & 0 & 1 & 0 & 1 & 157\end{array}$

$\begin{array}{llllllllllllllllll}230 & 0 & 0 & 2 & 0 & 0 & 4 & 9 & 11 & 9 & 31 & 0 & 20 & 0 & 1 & 0 & 2 & 89\end{array}$

$\begin{array}{llllllllllllllllll}235 & 0 & 2 & 3 & 0 & 4 & 2 & 7 & 12 & 8 & 35 & 0 & 12 & 0 & 1 & 0 & 0 & 86\end{array}$

$\begin{array}{llllllllllllllllll}240 & 0 & 2 & 2 & 0 & 5 & 0 & 4 & 6 & 12 & 18 & 1 & 10 & 0 & 1 & 0 & 1 & 62\end{array}$

$\begin{array}{llllllllllllllllll}245 & 0 & 2 & 1 & 0 & 1 & 1 & 3 & 6 & 7 & 8 & 1 & 6 & 0 & 0 & 0 & 1 & 37\end{array}$

$\begin{array}{llllllllllllllllll}250 & 0 & 0 & 1 & 0 & 2 & 2 & 1 & 2 & 2 & 11 & 0 & 3 & 1 & 0 & 0 & 1 & 26\end{array}$

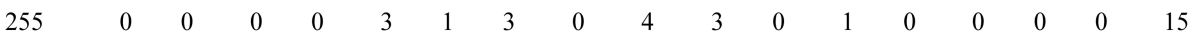

$\begin{array}{llllllllllllllllll}260 & 0 & 0 & 0 & 0 & 1 & 0 & 2 & 3 & 1 & 2 & 0 & 1 & 0 & 0 & 0 & 0 & 10\end{array}$

$\begin{array}{llllllllllllllllll}265 & 0 & 0 & 0 & 0 & 1 & 0 & 0 & 1 & 2 & 3 & 1 & 0 & 0 & 0 & 0 & 1 & 9 \\ 270 & 0 & 0 & 1 & 0 & 0 & 0 & 1 & 1 & 0 & 1 & 0 & 0 & 0 & 0 & 0 & 0 & 4\end{array}$

$\begin{array}{lllllllllllllllllll}270 & 0 & 0 & 1 & 0 & 0 & 0 & 1 & 1 & 0 & 1 & 0 & 0 & 0 & 0 & 0 & 0 \\ 7 & 0 & 0 & 0 & 0 & 1 & 0 & 0 & 0 & 0 & 3 & 1 & 1 & 0 & 1 & 0 & 0 & 7\end{array}$

$\begin{array}{lllllllllllllllllll}280 & 0 & 0 & 0 & 0 & 0 & 0 & 0 & 0 & 0 & 0 & 0 & 1 & 0 & 0 & 0 & 0 & 1\end{array}$

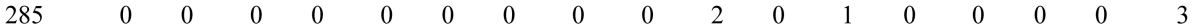

$\begin{array}{llllllllllllllllll}290 & 0 & 0 & 0 & 0 & 0 & 0 & 0 & 0 & 0 & 0 & 0 & 0 & 0 & 0 & 0 & 1 & 1\end{array}$

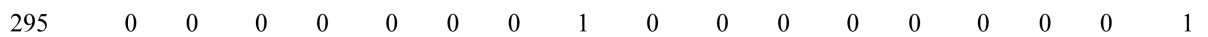

$\begin{array}{llllllllllllllllll}300 & 0 & 0 & 0 & 0 & 0 & 0 & 0 & 0 & 0 & 1 & 0 & 0 & 0 & 0 & 0 & 0 & 1 \\ 305 & 0 & 0 & 0 & 0 & 0 & 0 & 0 & 0 & 0 & 0 & 0 & 0 & 0 & 0 & 0 & 0 & 0\end{array}$

$\begin{array}{llllllllllllllllll}310 & 0 & 0 & 0 & 0 & 0 & 0 & 0 & 0 & 0 & 0 & 0 & 1 & 0 & 0 & 0 & 0 & 1\end{array}$

$\begin{array}{llllllllllllllllll}315 & 0 & 0 & 0 & 0 & 0 & 0 & 0 & 0 & 0 & 0 & 0 & 1 & 0 & 0 & 0 & 0 & 1\end{array}$

$\begin{array}{llllllllllllllllll}320 & 0 & 0 & 0 & 0 & 0 & 0 & 0 & 0 & 0 & 0 & 0 & 0 & 0 & 0 & 0 & 0 & 0\end{array}$

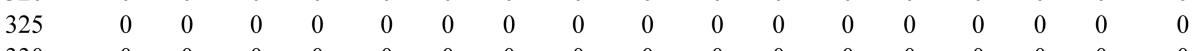

$330 \quad 00 \begin{array}{lllllllllllllllll} & 0 & 0 & 0 & 0 & 0 & 0 & 0 & 0 & 0 & 0 & 0 & 0 & 0 & 0 & 0 & 0\end{array}$

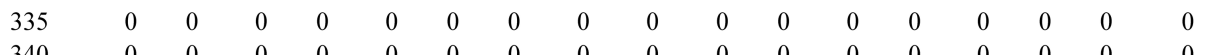

$\begin{array}{llllllllllllllllll}340 & 0 & 0 & 0 & 0 & 0 & 0 & 0 & 0 & 0 & 0 & 0 & 0 & 0 & 0 & 0 & 0 & 0\end{array}$

$\begin{array}{llllllllllllllllll}\text { Total } & 48 & 284 & 1080 & 46 & 1186 & 258 & 636 & 4479 & 4737 & 2521 & 174 & 1030 & 104 & 1005 & 18 & 673 & 18279\end{array}$

Vol. 49, № 3, 2014 


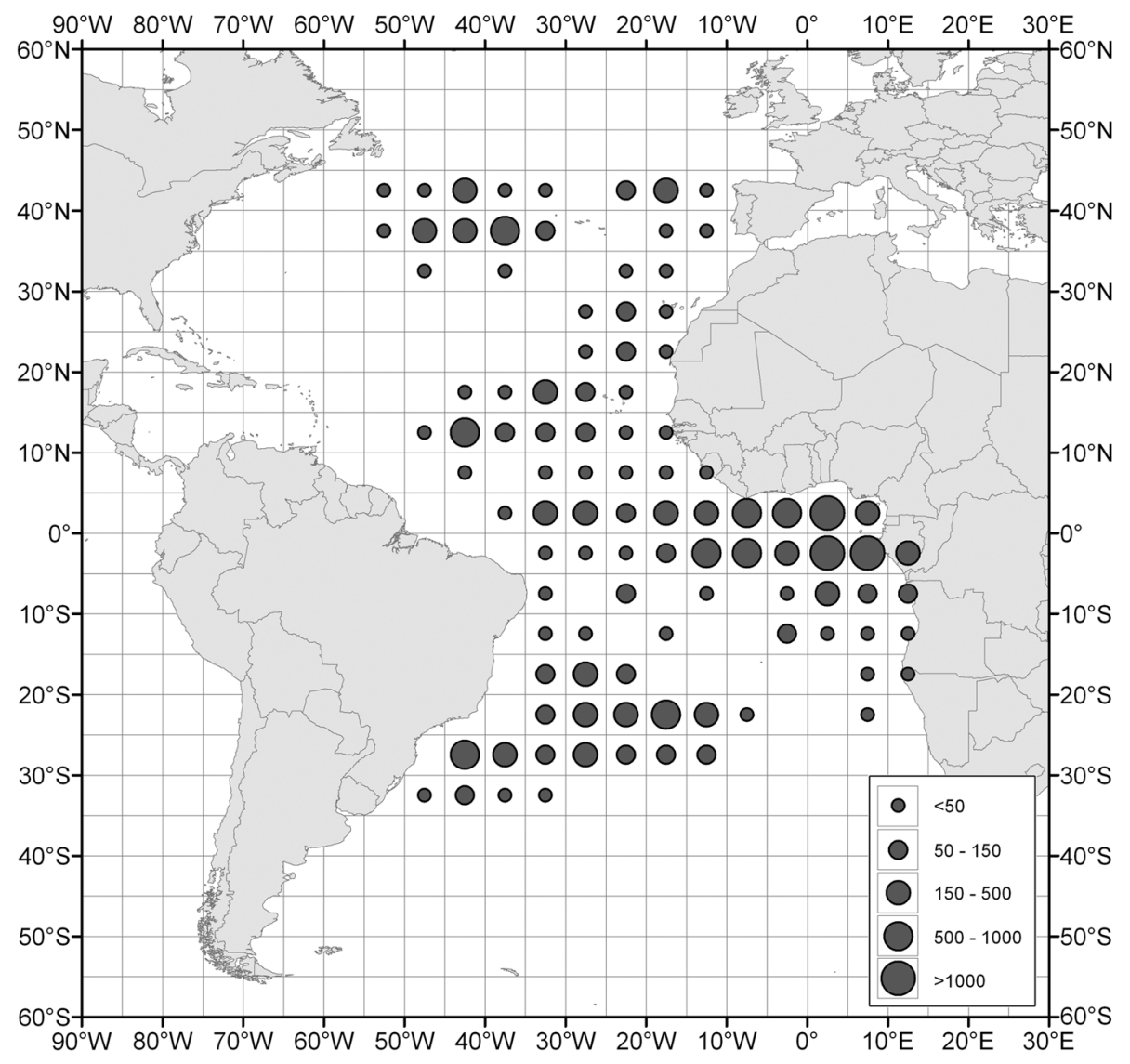

Figure 3. Geographic location and number of observations, in $5^{\circ} \times 5^{\circ}$ squares, of females with available gonadal index data (IG1), for all years and months combined / Localización geográfica y número de observaciones, en cuadrículas $5^{\circ} \times 5^{\circ}$, de las hembras con dato de índice gonadal disponible (IG1), para todos los años y meses combinados

gonads in adult females takes place mostly in warm waters with surface temperatures generally around such range. The unusual and sporadic observations of high IG1 values with temperatures of roughly $14^{\circ} \mathrm{C}$ corresponded to females of considerable size whose gonads showed aborted maturation processes, the development of tumours, etc. Their heavy gonads, full of eggs that had dried out, form a visible compact mass seen in the cross section cut.

The occurrence of each of the defined classifications of the gonadal indices in each $5^{\circ} \times 5^{\circ}$ square made it possible to identify areas with the most intense maturation activity in females (Fig. 5). The $5^{\circ} \times 5^{\circ}$ areas ranging from the western margin of the Atlantic between $10^{\circ} \mathrm{N}$ and $25^{\circ} \mathrm{S}$ to the West of $10^{\circ} \mathrm{W}$ exhibited the greatest gonadal maturation activity, in addition to some activity in some of the adjacent areas farther to the South. These results are even more evident when data are restricted to fishes LJFL > $145 \mathrm{~cm}$ showing that most of the specimens found in these areas are in advanced or very advanced gonadal maturation processes. The mean, maximum and minimum IG1 values by size class and region reveal characteristic patterns (Fig. 6). Some of the regions show no signs of significant maturation-reproduction processes (i.e., regions $01,02,03,12,15,91$ and 92 ). Others would suggest that the maturation-reproduction activity carried out may be sporadic, with relatively low mean values but also with some sporadic high maximum IG1 values (i.e., regions 06, 09, 11 and 93). Others would point to the highest level of maturation-reproduction activity from the standpoint of both mean and maximum IG1 values (i.e., regions 07, 08 and 13). The IG1 box-plots restricting the analyses to 

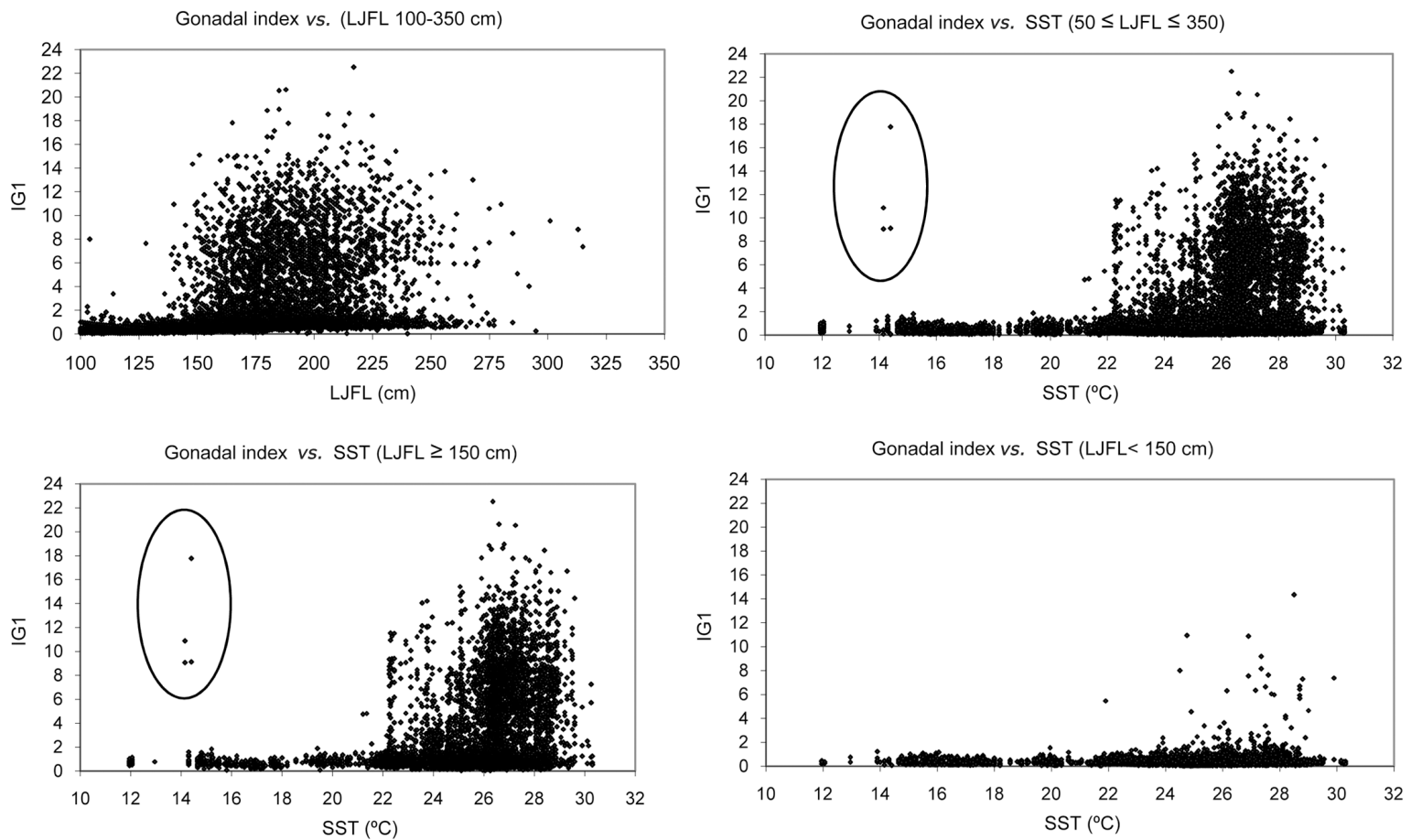

Figure 4. Gonadal index (IG1) in relation to female size and mean surface temperature SST $\left({ }^{\circ} \mathrm{C}\right)$ in the regions of capture and for different size ranges. The points inside the ellipse indicate atresic gonads or aborted spawning processes / Índice gonadal (IG1) en relación con la talla de las hembras y la temperatura superficial SST $\left({ }^{\circ} \mathrm{C}\right)$ en las regiones de captura y para diferentes rangos de talla. Los puntos dentro de la elipse corresponden a gónadas atrésicas o procesos de puesta abortados

a)

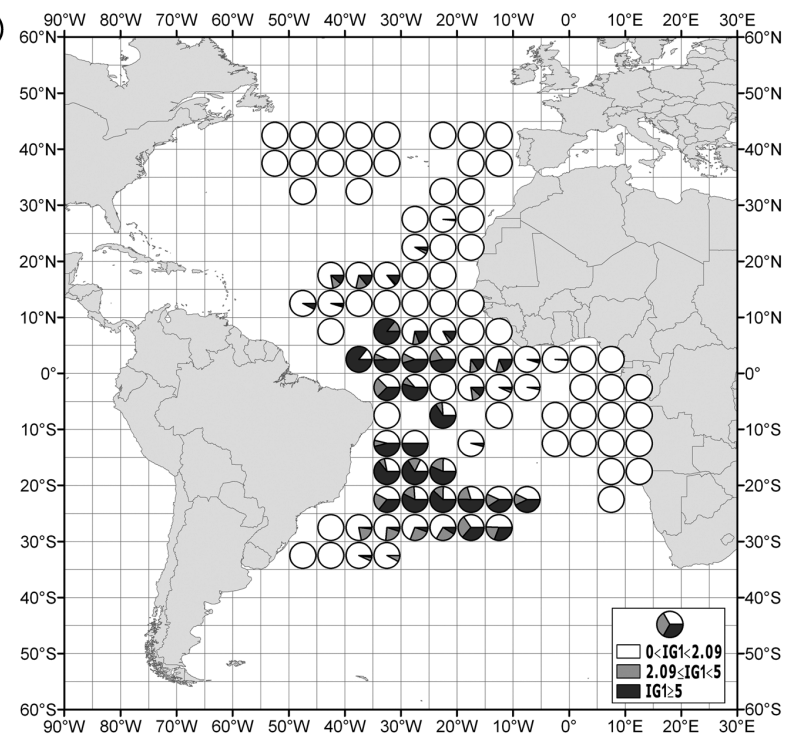

b)

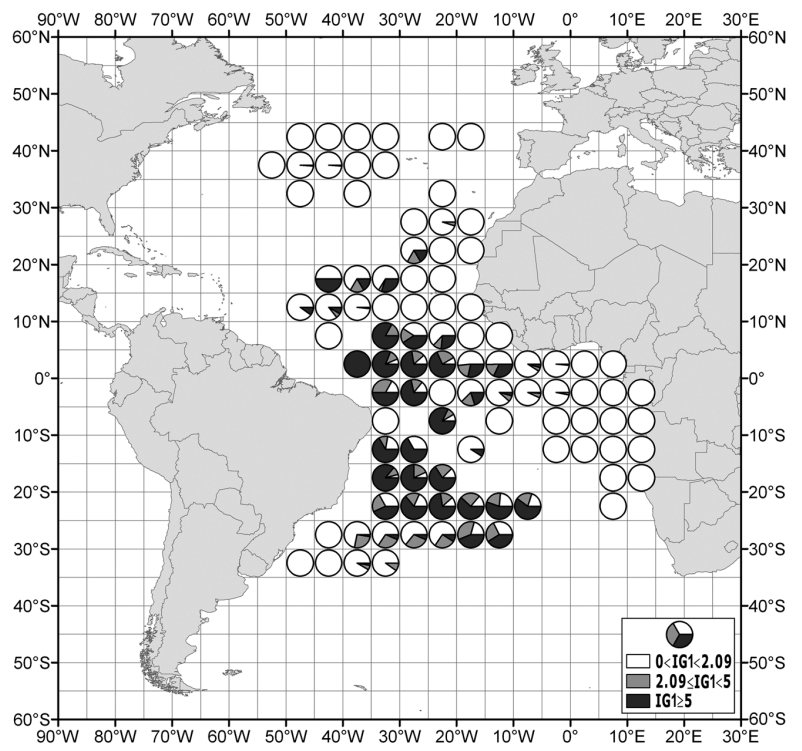

Figure 5. Occurrence of each of the three gonadal index (IG1) ranges defined, in each $5^{\circ} \times 5^{\circ}$ square observed, for females with a) sizes (50 $\leq$ LJFL $\leq 350 \mathrm{~cm}$ ), and b) sizes (LJFL $>145 \mathrm{~cm}$ ). White: no significant reproductive activity. Grey: perceptible reproductive activity. Black: very intense reproductive activity / Ocurrencia de cada uno de los tres rangos de índices gonadales (IG1), en cada cuadrícula de $5^{\circ} \times 5^{\circ}$ observada, a) hembras con tallas $(50 \leq \mathrm{LJFL} \leq 350 \mathrm{~cm}$ ) y b) tallas (LJFL $>145 \mathrm{~cm}$ ). Blanco: sin procesos reproductivos significativos. Gris: actividad reproductiva perceptible. Negro: actividad reproductiva muy intensa 

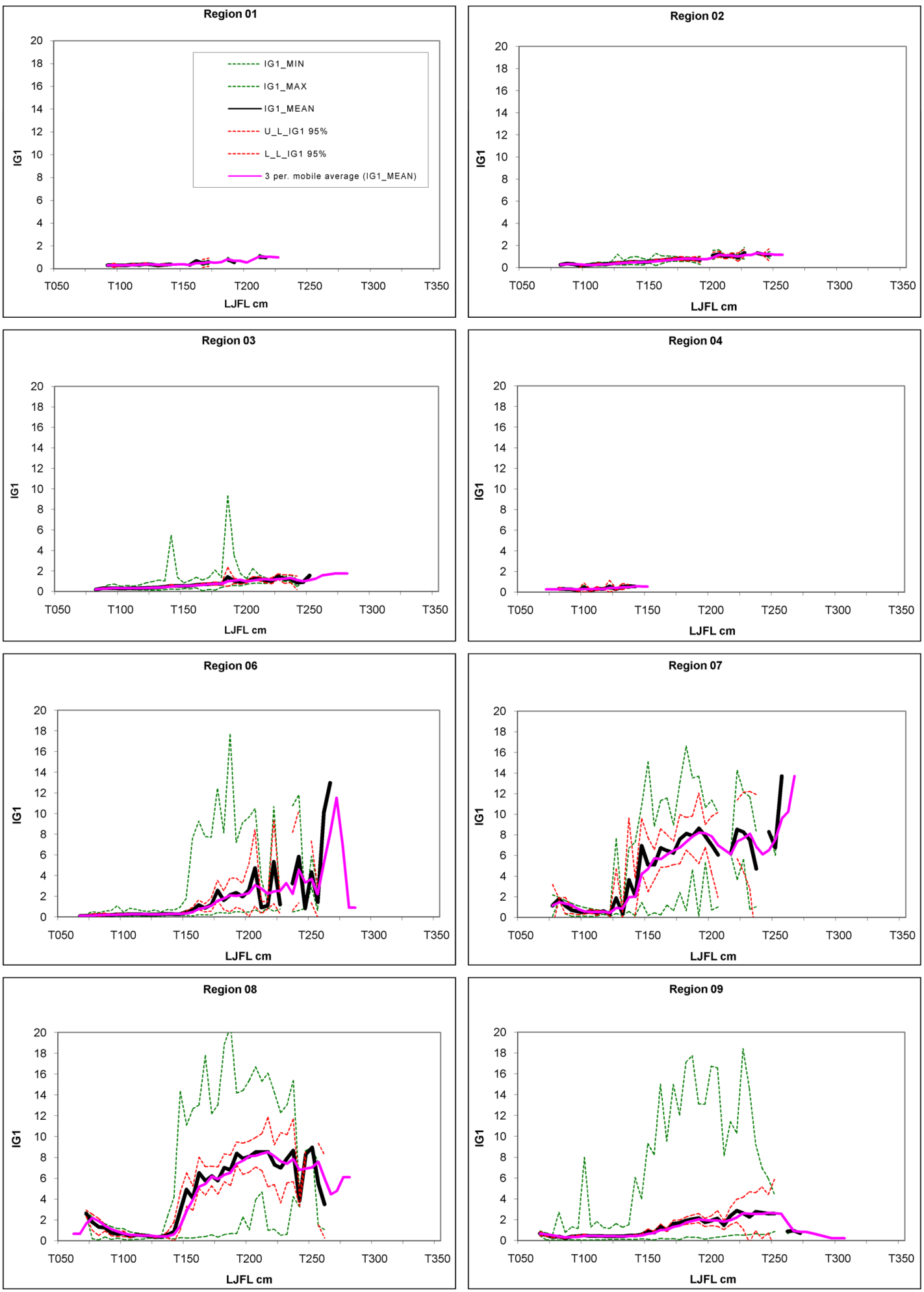

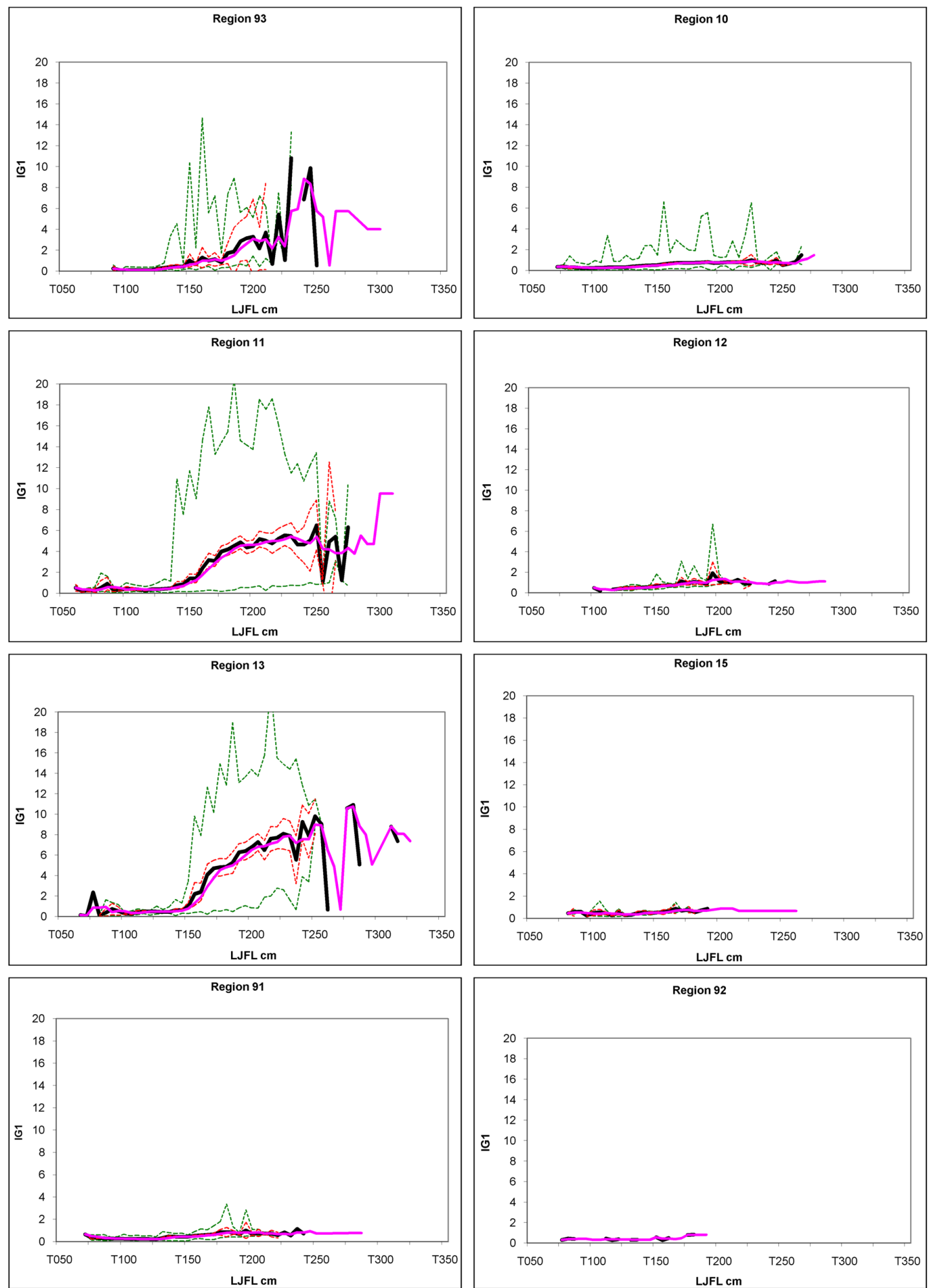

Figure 6. Gonadal indices (IG1) by region and size class (LJFL). Mean values (black line), 95\% confidence interval (dotted red line), minimum and maximum values (dotted green line) and mobile mean (purple line) / Índices gonadales (IG1) en cada región y por clase de talla (LJFL). Valor medio (línea negra), intervalo de confianza 95\% (línea roja discontinua), valores mínimos y máximos (línea verde discontinua), media móvil (línea púrpura continua) 
females with a size class of LJFL > $145 \mathrm{~cm}$ also highlight the substantial differences among regions (Fig. 7) and support the conclusions drawn in the analyses by size class. Regions 07, 08 and, to a lesser extent region 13, exhibit an important reproductive pattern that is consistent and relatively homogeneous, while the adjacent regions 06, 09 and 93, show generally low IG1 values, but with a considerable number of high IG1 outliers. This would suggest that in these adjacent regions the most common situation is the occurrence of females in resting stages or still immature, but having sporadic episodes of maturation possibly seasonal in nature. On the basis of these analyses, it could be concluded that regions 07,08 and 13 are the ones that show the greatest gonadal maturation activity even for relatively small females, along with a moderate activity in some of the adjacent regions, especially region 11 , and to a lesser extent, regions 09,06 and 93.
The IG1 data by month for regions 06, 07, 08, 09, 11, 13 and 93 would suggest the presence of seasonal reproductive behavior in some (Fig. 8). Regions 07 and 08 show high IG1values during all the months sampled, with minor differences between months observed. However region 13, which is adjacent to region 08 , appears to have a seasonal pattern with the highest IG1 values in January, February and December (austral summer) versus the relatively low values in March, April and May (austral autumn). This would suggest that this region may be potentially reproductive only under certain circumstances related to temperature during the austral summer. Considering the observations as a whole, it is possible to define a three-dimensional graphic model describing the region-month behavior of reproduction based on the IG1 values. The presence of maturation-reproduction processes is restricted to some of the regions during all of the months sampled and seasonal or sporadic activity is observed in the adjacent regions (Fig. 9).

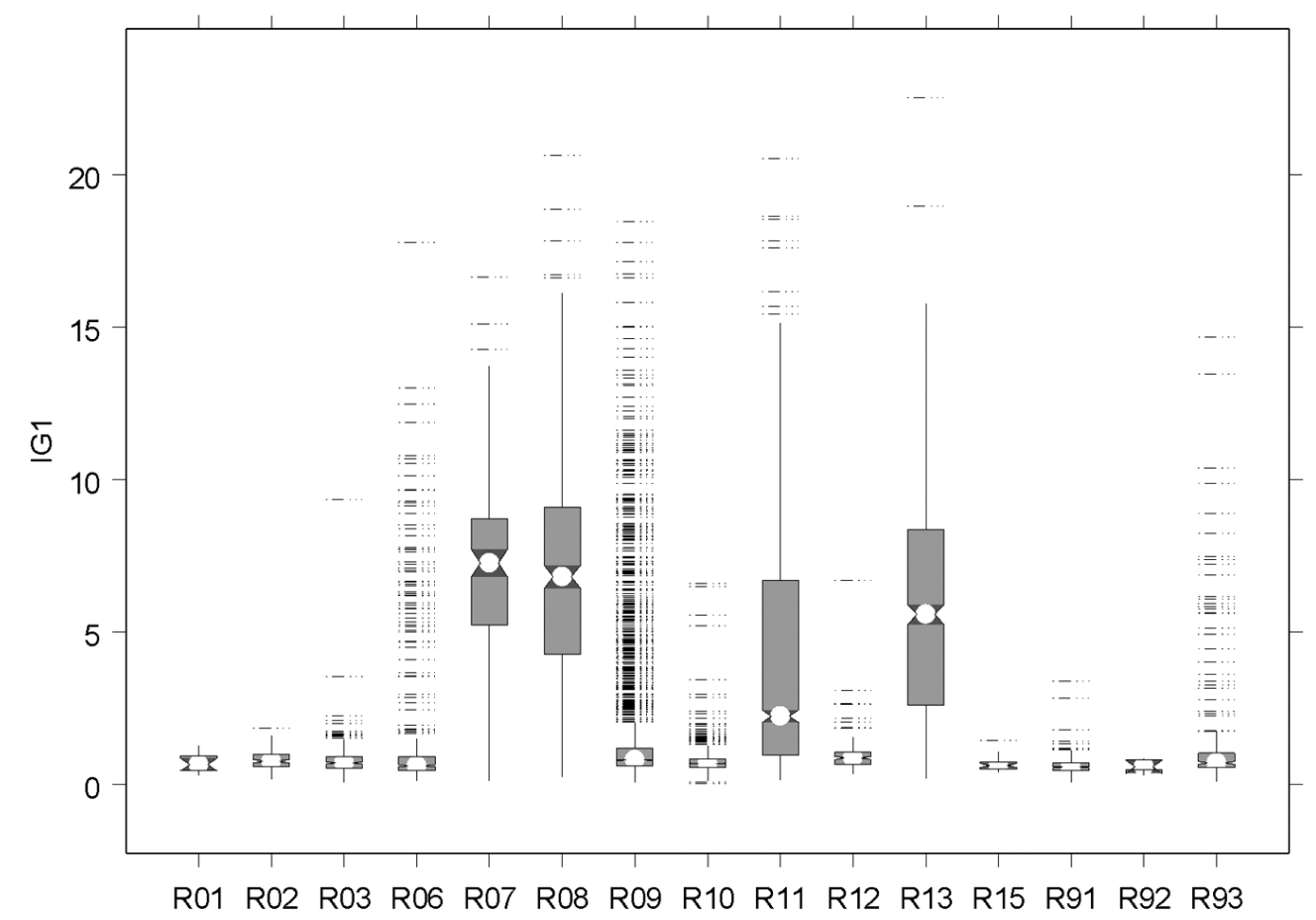

Figure 7. Box-plot of the gonadal indices (IG1) by region for females with size LJFL $>145 \mathrm{~cm}$ and for all the months combined / Diagrama-caja de los valores de índices gonadales (IG1) por región, para hembras con tallas LJFL > $145 \mathrm{~cm}$ y para todos los meses combinados 

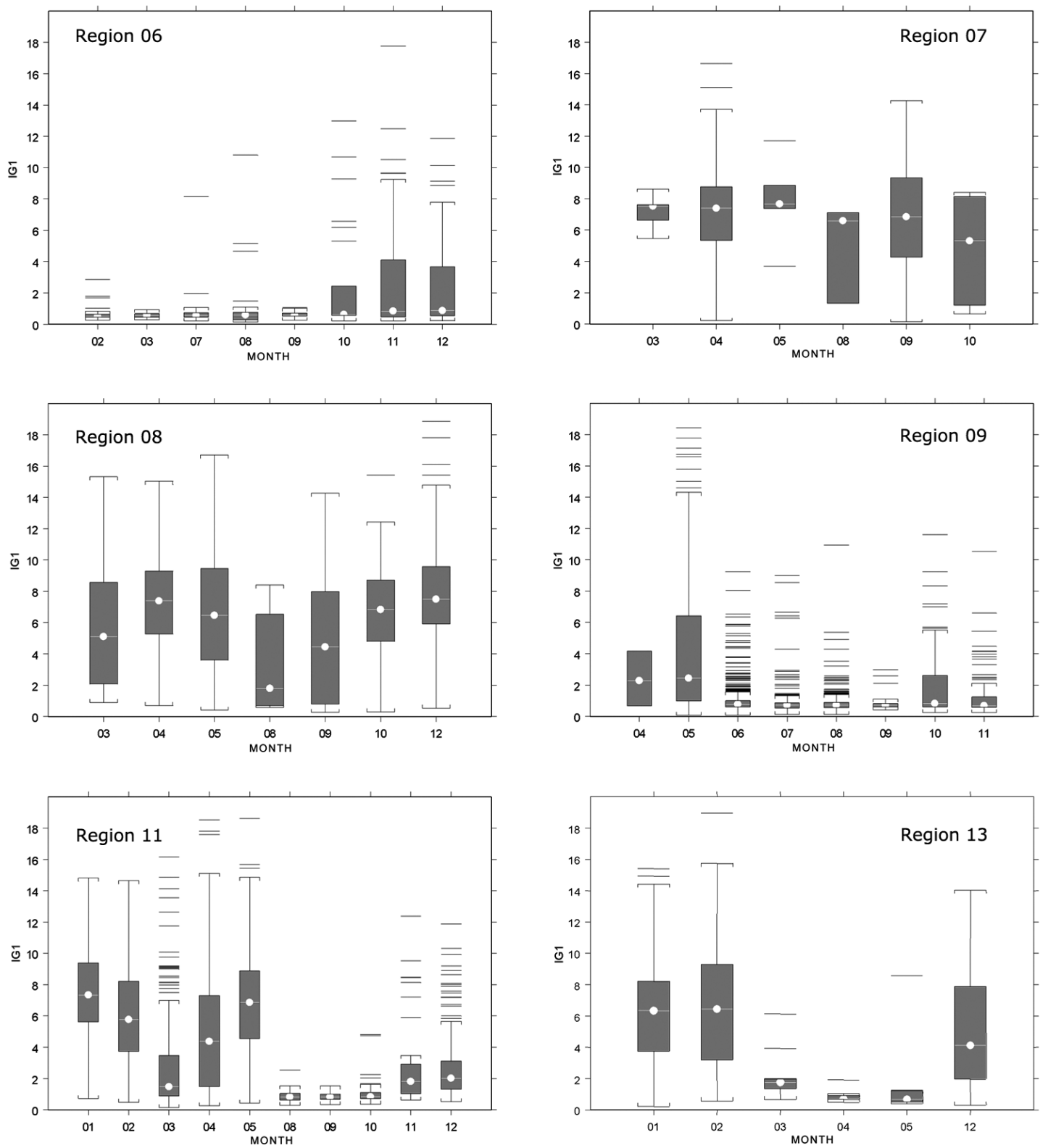

Figure 8. Box-plot of the observed gonadal indices (IG1) of females with size LJFL $>145 \mathrm{~cm}$, by month and for regions $06,07,08,09,11,13$ and 93 / Diagramacaja de los índices gonadales observados (IG1) en las hembras con talla LJFL $>145 \mathrm{~cm}$, por mes y para las regiones 06, 07, 08, 09, 11, 13 y 93

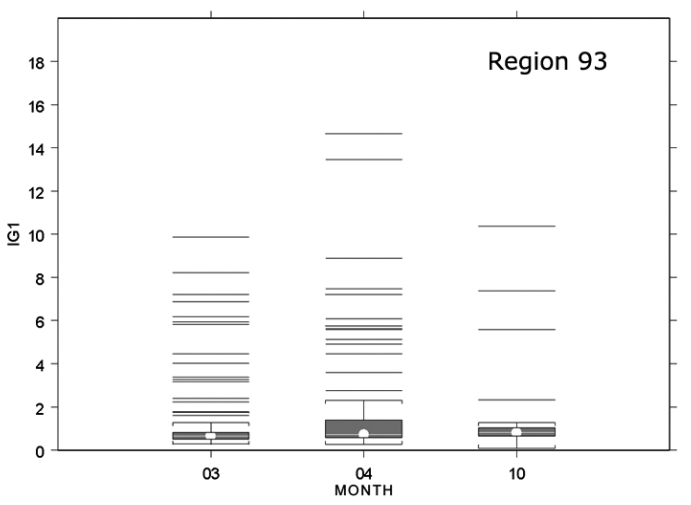




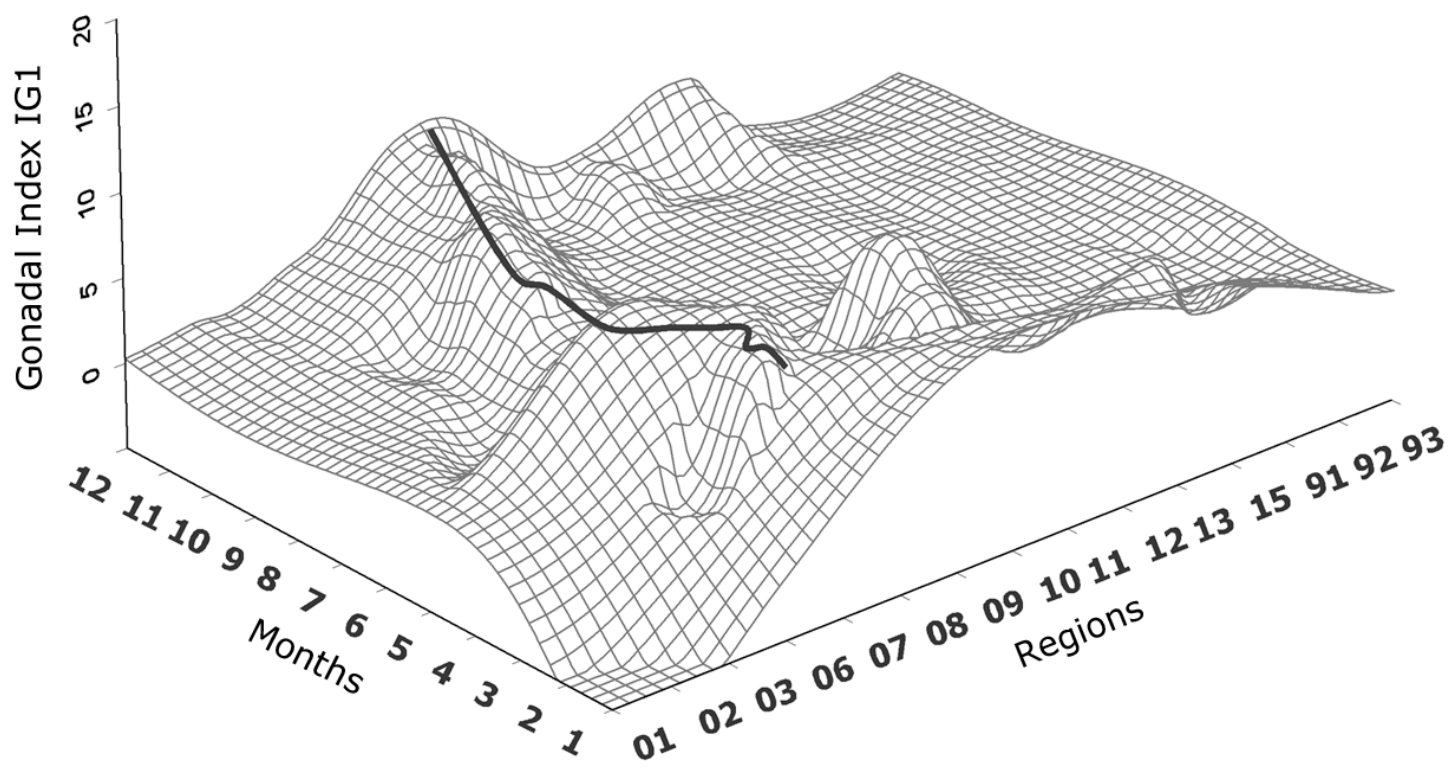

Figure 9. Three-dimensional spline interpolation plot of the observed gonadal indices (IG1) of female swordfish (LJFL $>145 \mathrm{~cm}$ ) of the Atlantic Ocean, by month and region / Gráfico tridimensional con interpolación tipo 'spline' de los índices gonadales (IGI) observados en las hembras de pez espada (LJFL $>145 \mathrm{~cm}$ ) del océano Atlántico, por mes y región

The results obtained highlight the consistency of regions 07 and 08 in relation to the presence of females in maturation-spawning processes as opposed to other regions analyzed in which these processes are seasonal, sporadic or non-existent. In light of the above, these two regions were selected as a suitable group of samples on which to base the estimation of the size at first maturity using the proportion of females present in the two regions and distinguishing between females with IG1 $<2.09$ and IG1 $\geq 2.09$, respectively. Size $\mathrm{LJFL}_{50}$ was estimated at 146.5 $\mathrm{cm}$ and the maturity fraction of females defined as: $p_{\mathrm{m}}=1$ $/\left(1+\mathrm{e}^{(-0.1398(\mathrm{LJFL}-146.5))}\right),\left(\mathrm{r}^{2}=0.968\right.$, Prob $\left.>\mathrm{F}=0.024\right)$, (Fig. $10)$.

The R_CPUEn and R_CPUEw by sex show regions 07 and 08 having ratios that differ from those of other regions, especially R_CPUEn which reaches values ranging from 3.3 to 4.0 times higher in males, respectively, and more moderate values of R_CPUEw. The CPUE data by size class of these two regions point to size group $125-165 \mathrm{~cm}$ LJFL (R_CPUEL2) as being the cause of the high CPUEn of males up to 11.2 and 9.5 times higher than females, while at the same time exhibiting lower CPUEL2_F values in these regions than in adjacent regions. The anomalies of the R_CPUE indicate that the regions in which maturation-reproductive processes were detected in females usually show the highest positive anomaly with males clearly prevailing in the $125-165 \mathrm{~cm}$ size range where most of the reproductively active males are concentrated (Fig. 11). Mature females may be caught on the longline in the areas where reproductive processes are observed and it is common to see one or more males chasing or courting the mature female, even right up to the side of the vessel until the female is hauled on board (Fig. 12).

The gonadal stage of 18,283 females was also examined. The stages not showing significant maturity (stages 1,2 and 3) dominated the observations in most regions when all sizes are combined $(50 \leq \mathrm{LJFL} \leq 350 \mathrm{~cm})$. This may be attributed to the high prevalence of immature females and resting adult females in most observed regions. The occurrence of stages 4 and 5 in regions 07,08 and 13 account for $37 \%, 33 \%$ and $14 \%$ of all the sizes combined. Nevertheless, their occurrences reach values of $64 \%, 51 \%$ and $28 \%$ of the females, respectively, when the analysis is restricted only to females size classes LJFL $>145 \mathrm{~cm}$ (Fig. 13). The qualitative analysis is also capable of distinguishing between regions having very little or no maturation activity and regions with a high reproductive 


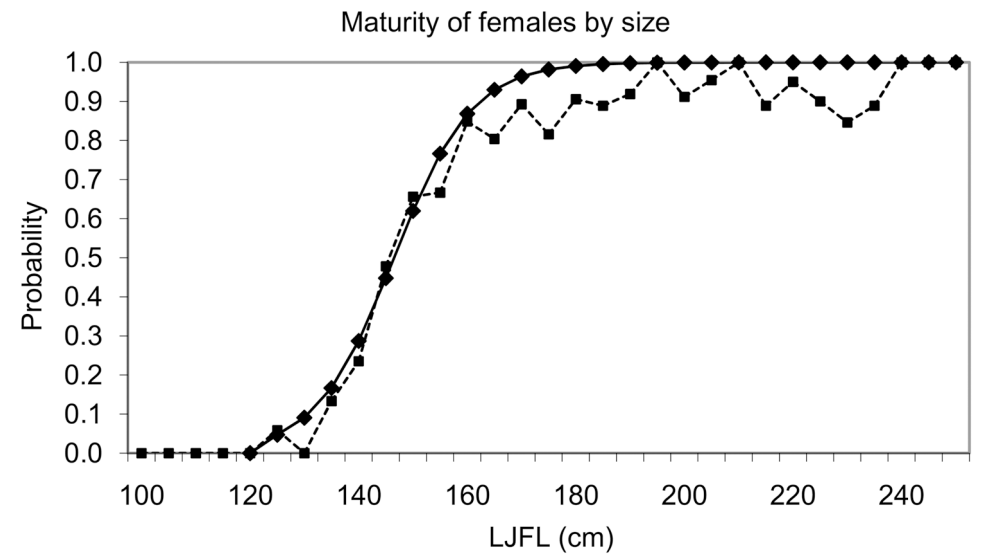

Figure 10. Probability of females, by size class, that showed signs of gonadal maturation in the regions 07 and 08 combined ( $N=808)$ ranging from 100 to $250 \mathrm{~cm}$ LJFL. Observed values: broken line. Fit line: solid line, $\mathbf{p}_{\mathrm{m}}=1 /\left(1+\mathrm{e}^{(-0.1398(\text { (LF-146.5))})} /\right.$ / Probabilidad de hembras, por clase de talla, que mostraron signos de maduración gonadal en las regiones 07 y 08 combinadas $(N=808)$, para el rango de tallas entre 100 y 250 cm LFL. Valores observados: línea discontinua. Línea del ajuste: línea continua, $\mathrm{p}_{\mathrm{m}}=1 /\left(1+\mathrm{e}^{(-0,1398(\mathrm{UFL}-146,5))}\right)$
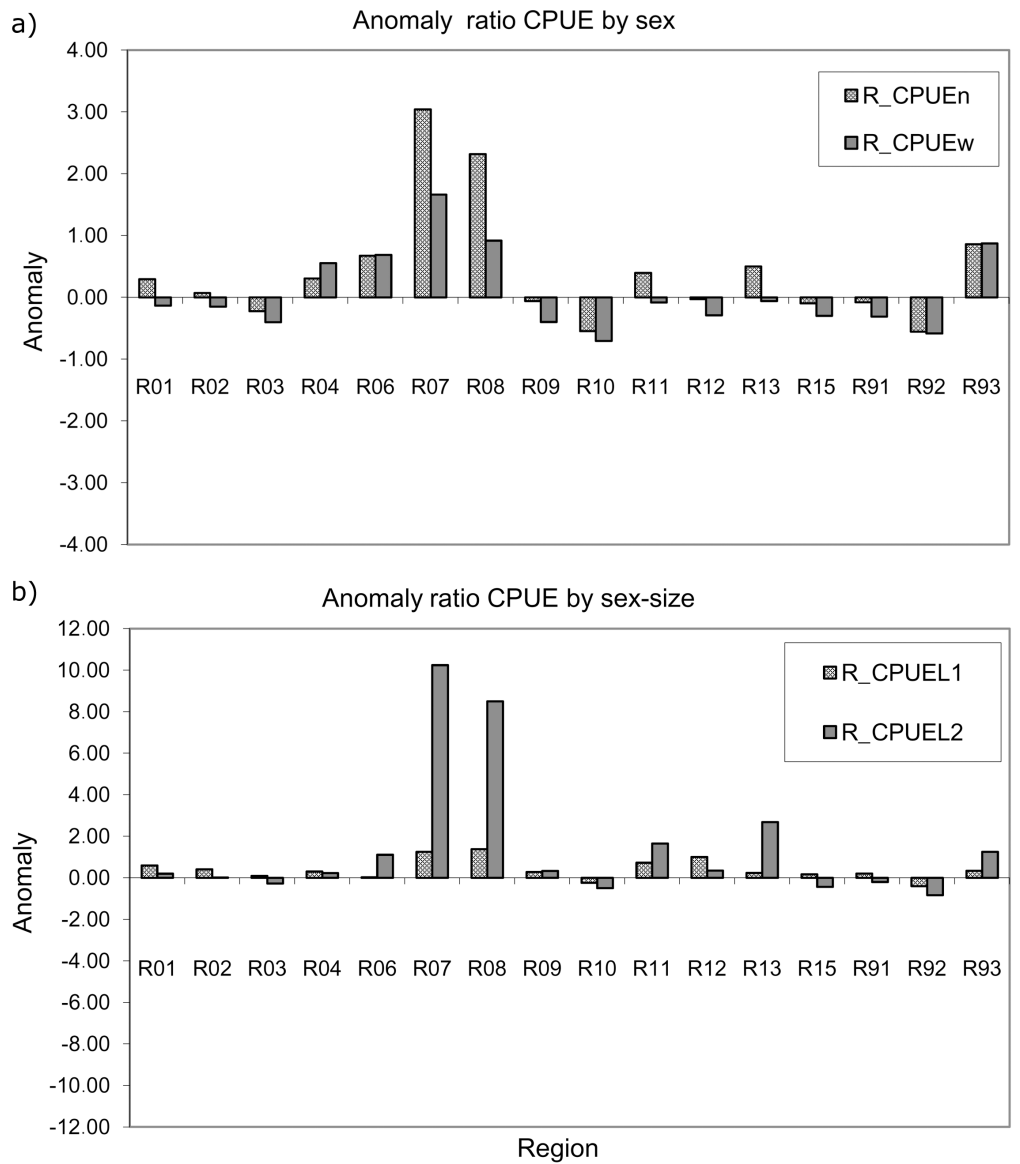

Figure 11. Anomalies observed by region of the ratio between CPUE by sex (males/ females), a) in number of fish (R CPUEn) and kilograms (R_CPUEw). b) Anomalies in number of fish for the size classes of 50-120 cm (R_CPUEL1) and 125-165 cm (R_CPUEL2) / Anomalías observadas por región del ratio entre la CPUE por sexo (machos/hembras), a) en número de peces (R_CPUEn) y en kilogramos (R_CPUEw). b) Anomalía en número de peces para las tallas 50-120 cm (R_CPUEL1) y $125-165$ cm (R_CPUEL2) 

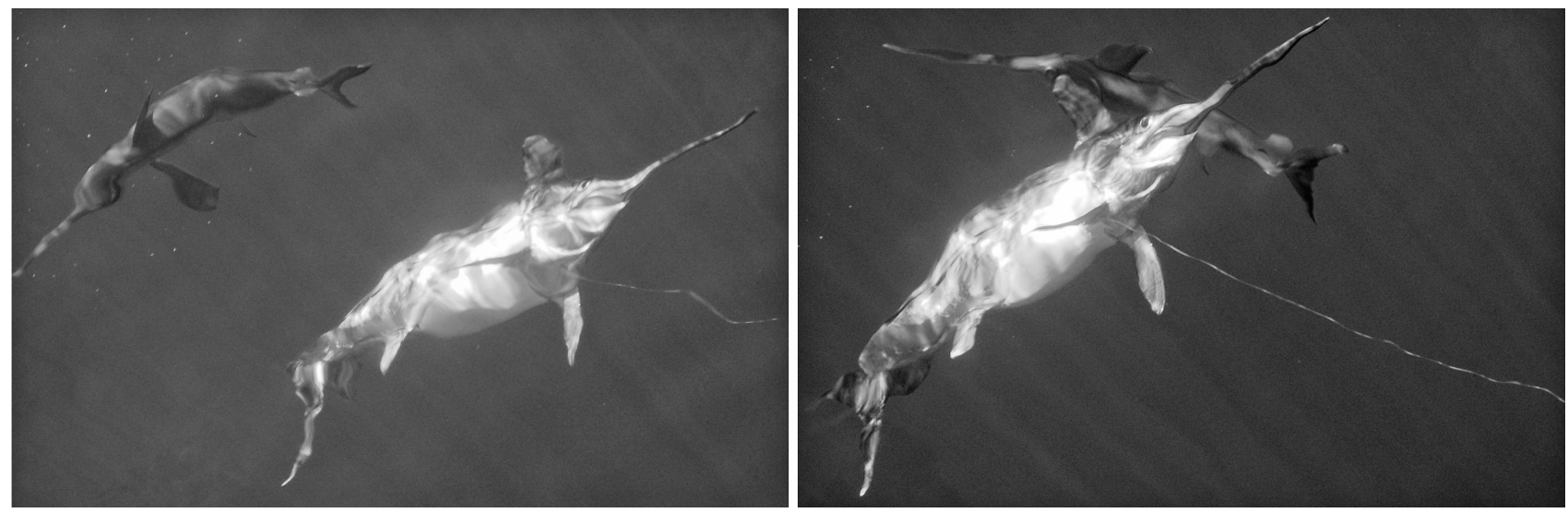

Figure 12. Male swordfish (in the background) chasing an adult female caught by a surface longline (foreground). The female, which presented mature gonads close to spawning with a visibly swollen visceral cavity, is 'courted' by the marauding male (pair) until the female fish was hauled onboard. Photograph taken by Gonzalo Molins / Macho de pez espada (en segundo plano) persiguiendo a una hembra adulta capturada por un palangre (en primer plano). La hembra, que presentó gónadas muy maduras próximas a la puesta, con una cavidad visceral visiblemente dilatada, es 'cortejada' por el macho merodeador (pareja) hasta que fue izada a bordo. Fotografía tomada por Gonzalo Molins
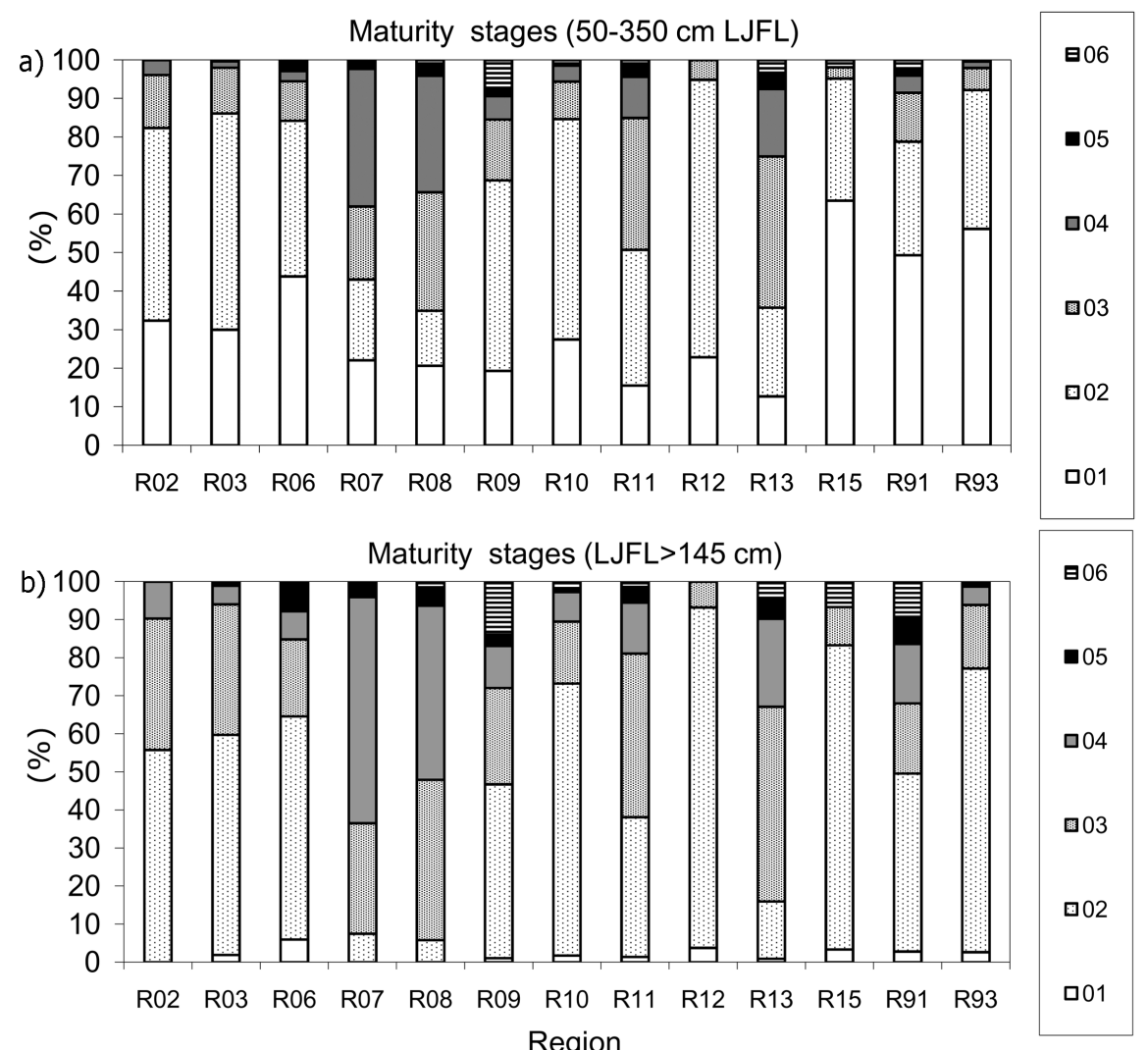

Figure 13. Percentage of females presenting each of the 6 maturity stages in each of the defined regions. a) all sizes $50-350 \mathrm{~cm}$ LJFL. b) sizes LJFL $>145 \mathrm{~cm}$. (Regions with less than 30 observations LJFL $>145 \mathrm{~cm}$ were excluded in both plots) / Porcentaje de hembras presentando cada uno de los 6 estados de madurez en cada región definida. a) tallas 50-350 cm LJFL. b) tallas LJFL $>145 \mathrm{~cm}$. (Las regiones con menos de 30 observaciones LJFL > $145 \mathrm{~cm}$ fueron excluidas en ambos gráficos) 


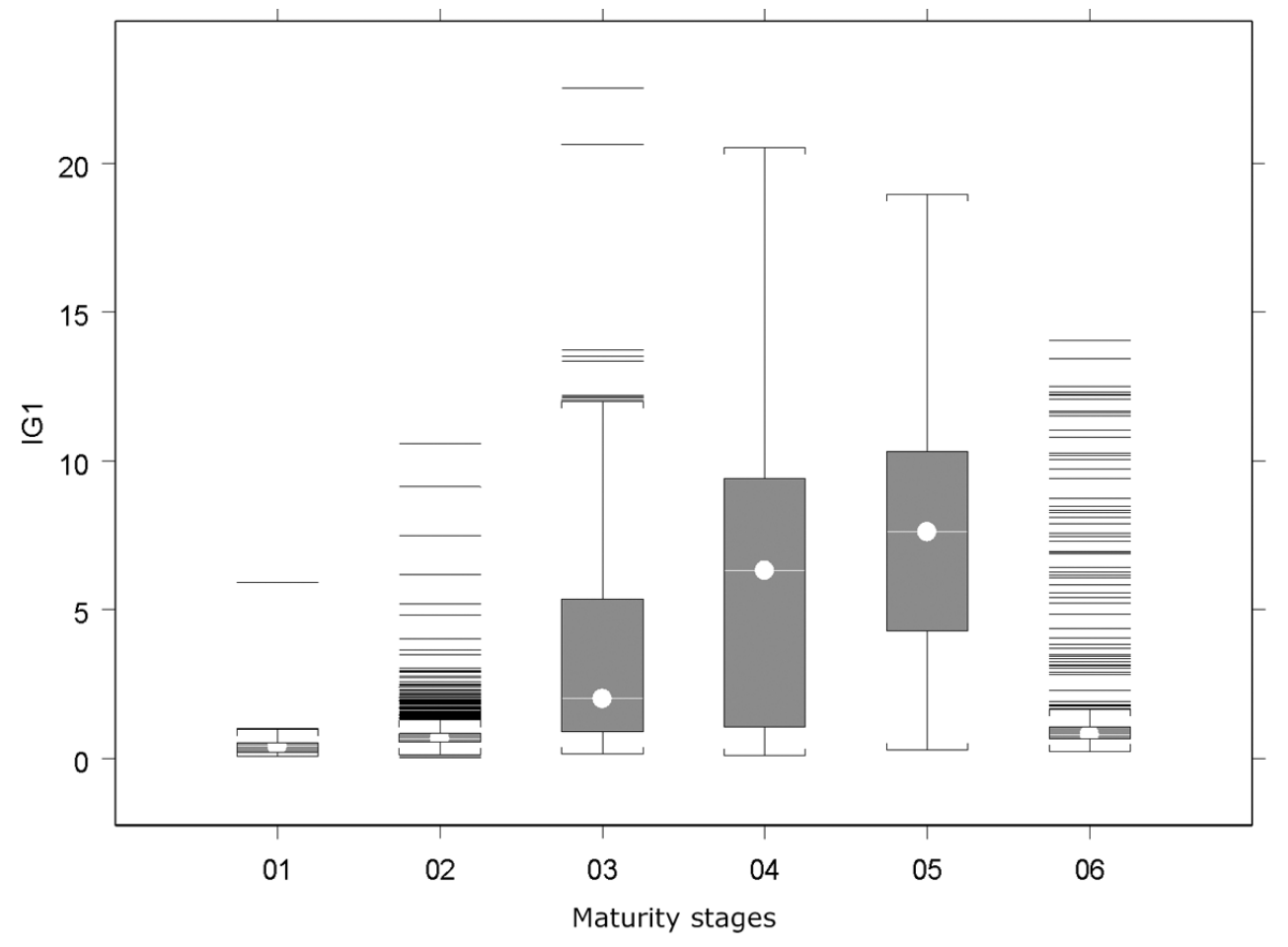

Figure 14. Box-plot of the gonadal indices (IG1) in relation to each of the 6 different maturity stages identified / Diagramacaja de los índices gonadales (IG1) en relación con cada uno de los 6 estados de madurez identificados

activity. The qualitative results corroborate the highest reproductive activity in some of the regions (such as 07 , 08 and 13) but also the sporadic or moderate reproductive activity in adjacent regions. Despite the subjective nature of the identification of the maturity stages and the limited quality of the information from temperate areas, the macroscopic-qualitative identifications generally do coincide quite well with the gonadal indices obtained (Fig. 14).

\section{Discussion}

Most studies carried out to date on the reproduction of the swordfish have basically followed two methodological strategies: a) the analysis of female gonad samples using microscopic-histological studies or b) the analysis of quantitative or qualitative macroscopic indicators of the gonadal developmental stage and maturity of the females. A third alternative is the identification of the areas-times of larval presence (Palko et al. 1981, Govoni et al. 2000). However, owing to currents, larvae tend to drift rapidly and therefore the presence of these stages would not ensure the correct identification and delimitation of the areas used by this species for maturation or spawning or the correct identification of adult individuals found in these zones as breeders. The respective advantages and disadvantages of the first two strategies for the study of fish reproduction have long been discussed. However, the two approaches should not be considered mutually exclusive, but rather complementary (West 1990). The first methodological approach has the advantage of providing information on the degree of development of the different stages exhibited by the oocytes in each gonad and their respective occurrences, estimations on maturity, temporal reproductive patterns, etc. (i.e., Arocha 1997, 2002; Aranda et al. 2013, Poisson \& Fauvel 2009b). It does however have its drawbacks, in that it is difficult to obtain, preserve and analyze the samples collected from such a largebodied, hard-to-handle species and to preserve them for long periods at sea in commercial vessels. So, the availability of samples for this type of analysis has usually been rather limited in quantity and spatial-temporal coverage. The second method offers the advantage of 
presenting information on the general status of maturation in the gonads of each female without having to preserve the samples obtained and eliminating the need to transport them and carry out subsequent analyses. This option is a good approach for initializing the study of several different reproductive variables of this species (areas, times, spawning sizes, etc.) with a broad population focus, which requires fairly large representative samplings on commercial vessels in which the mass preservation of samples is difficult for this type of species. The second approach, used in this paper, is a very useful procedure and would be advisable prior to conducting histological studies selecting specific areas. Size classes and size groups have been considered in this paper in order to reduce the potential bias of these methods when samples of fish having different body sizes are compared (West 1990). A previous study has focused jointly on both alternatives to be able to determine and validate, in the case of female swordfish, the relationship that exists between the histological observations and the biometric indicators (gonad weight) (Hinton et al. 1997). Using this strategy, it was possible to establish threshold values of the biometric indicators of maturity in females and to relate them to the histological observations of a smaller-sized sub-sampling (Cayre \& Laloe 1986). Most of the studies on swordfish reproduction have been based on relatively small sampling sizes and/or from restricted areas-times which limit the degree to which the results may be generalized.

Within the methodological approach based on macroscopic-biometric indicators for reproductive studies, the majority of authors have used different formulations of gonadal indices (Yuen 1955) on the basis of the relationship between the gonad weight and the body weight of the female (or the equivalent in length). Previous studies on swordfish suggested that the gonadal index values IG $\geq 3.0$ (Kume \& Joseph 1969) or IG $\geq 1.375$ (Hinton et al. 1997) would be a good indication of females in active stages of maturation or spawning, according to the respective formulations using both the weight of female gonads and the eye fork-length size (EFL). The equivalent of these thresholds would correspond respectively to values 2.09 or 1.346 when the standard LJFL size is used (Mejuto \& García-Cortés 2003b). IG1 values under the selected threshold 2.09 would indicate an insignificant activity of gonadal development or maturation, whereas values equal to or greater than the threshold would point to gonadal development, maturation or reproductive activity (Cayre \& Laloe 1986).
There has been no precedent in studies on the reproduction of the Atlantic swordfish as regards the sampling size and geographical range covered in this paper. However, the few observations for regions 91 and 93 came mostly from the easternmost areas. Conclusions reached for these two regions and others with low sampling coverage should be considered preliminary until more representative sampling can be achieved. Regions 01, 02 and 04 have borne highly intensive fishing for decades and have been the subject of investigation on a large sampling size which did not find evidence of reproductive processes (García \& Mejuto 1988). For this reason, the bulk of the sampling effort was directed at other regions, particularly those with an expected high reproductive potential about which little or no information had been previously reported. The definition of regions used was based on previous studies on sex-ratios at size and it is assumed by the International Commission for the Conservation of Atlantic Tunas (ICCAT) as a standard stratification of the size-sex-area data. This criterion also enables a relationship to be drawn between the results obtained in this paper and the characteristic patterns of sex-ratio at size (spawning, transitional and feeding) previously defined as biological regions for the Atlantic swordfish (Mejuto et al. 1994, 1995, 1998, Turner et al. 1997, Mejuto 2007) later summarized in Neilson et al. (2013).

The methodology used to obtain $\mathrm{LJFL}_{50}$ reduces some of the bias that would occur if observations of very large females in a temporary gonadal resting stage were included in the linear fit and interpreted as not ever having reached sexual maturity. The value $146.5 \mathrm{~cm}$ obtained would be in the range of 3 to 4 year old animals according to most of the growth studies carried out for the Atlantic swordfish using both hard parts and tag-recapture data (Esteves et al. 1995). A sensitivity analysis, including some large resting females, provided a very similar value of $150.8 \mathrm{~cm}$ $\mathrm{LJFL}_{50}$. These values are lower than those estimated for the NW Atlantic by other authors who used samples generally obtained from subtropical areas around the Caribbean, Florida and the Antillian Arch. On the basis of several studies conducted in the above-mentioned regions, it was assumed that swordfish females started maturing sexually $\left(\mathrm{LJFL}_{\min }\right.$ ) at around $170 \mathrm{~cm} \mathrm{LJFL}$ and reached the first maturity size $\left(\mathrm{LJFL}_{50}\right)$ between 170-189 $\mathrm{cm}$. Theses sizes correspond on average to an age ranging from 5 to 5.5 years (Arocha 1997, DeMartini 1999, Anonymous 2000). However, the size at first maturity was regularly defined in the Mediterranean as being lower than that of the North Atlantic, with $\mathrm{LJFL}_{50}$ values ranging 
between 135 and $145 \mathrm{~cm}$ (De la Serna et al. 1992, 1996; Demetrio et al. 1989). The results attained in this paper indicate that both $\mathrm{LJFL}_{\text {min }}$ and $\mathrm{LJFL}_{50}$ are lower than the values previously described for the subtropical NW Atlantic areas. The discrepancy between estimations could be due to the respective methods used and the different sampling areas-times and groups of fish selected. Values of $162 \mathrm{~cm}$ and $170 \mathrm{~cm} \mathrm{LJFL}_{50}$ have been described for the Pacific-Hawaii areas (DeMartini et al. 2000) and for Indian-La Reunion areas (Poisson \& Fauvel 2009a) respectively. The latter paper used a similar method based on thresholds of the gonadal index but only fish greater than $165 \mathrm{~cm}$ sampled during the spawning season under consideration were studied in that analysis. Previous studies generally used histological cuts performed on females obtained from specific regions-times in the subtropical NW Atlantic where abundant large females at rest as well as some large mature specimens can be found mixed together depending on the areas-times sampled (Arocha 1997, 2007). The samples selected in this paper originate exclusively from regions exhibiting a considerable amount of maturation-reproductive activity which is known to occur year round. Not only do regions 07 and 08 present intense and consistent maturationreproduction patterns, they also show more stable thermal conditions throughout the year. Female size-age must be considered a condition that is necessary for the start of maturation processes and gonadal development, but it is not sufficient in itself (Mejuto 1999). Increasing the IG1 threshold to estimate the size at first maturity would not have a significant impact on the $\mathrm{LJFL}_{50}$ value obtained. The IG1 values were extremely high in regions 07 and 08 , with values usually greater than 4 . Therefore, the results would not be significantly affected by increasing this threshold within a reasonable biological range. Moreover, the threshold value of 1.375 defined in EFL units and validated histologically for the Eastern Pacific areas (Hinton et al. 1997) is equivalent to the threshold of 1.945 when the Kume \& Joseph (1969) formulation is used in LJFL units (Mejuto \& García-Cortés 2003b). Hence, the threshold selected in our case $(\mathrm{IG} 1=2.09)$ is more conservative and demanding when defining the maturation activity in females than the threshold used in other studies (Hinton et al. 1997, Poisson \& Fauvel 2009a). It is especially interesting to note that the $\mathrm{LJFL}_{50}$ value obtained here comes closer to the values defined for the Mediterranean stock, which would suggest that the reproductive parameters of the Atlantic and Mediterranean swordfish may not be as different as previously thought.

The temperature of the surface layers as a whole and their thermal structure (thermocline) could be key elements favouring and leading to the start of maturationreproduction processes rather than surface temperature (Mejuto \& Hoey 1991). The results obtained herein would suggest that this relationship between seawater temperature and the development of maturation processes in female gonads does in fact exist. Seasonal expansioncontraction processes of the warm water surface layers generally higher than $23^{\circ}-24^{\circ} \mathrm{C}$ - could play an important role in explaining the presence-absence of reproductive phenomena in the adjacent regions to the most active reproductive regions identified. Similar processes would also be expected to exert important effects on the maturation and reproduction phenomena observed in some regions-months of the Caribbean and Antillian Arch, where similar processes have also been reported for this species (Arocha 1997) or in the Indian Ocean (Poisson \& Fauvel 2009a). In this sense, despite the low number of observations available from region 93, the results obtained generally suggest low IG1 values, but also some sporadic maturation processes in large females in March and April, most likely as a result of the fact that the area is adjacent to regions 07 and 08 , or to the spawning activity of the large females in the NW Atlantic, South of the Sargasso Sea and North of the Antillian Arch defined earlier and previously reported (Arocha 1997).

Special attention should be paid to the lack of significant maturation activity observed in females sampled in the intertropical areas East of $10^{\circ} \mathrm{W}$, ruling out a previous hypothesis that the reproduction of this species in the Atlantic occurs throughout the entire intertropical band (Rey 1988). Although the SSTs are quite homogeneous in the intertropical areas -which is what led to that assumption- a substantial difference in temperature and thermocline is observed between the surface layers on both sides of the Atlantic (see Maps from World Ocean Atlas Data, NOAA ${ }^{1}$ ). According to the results, it is plausible that the temperature taken at $50 \mathrm{~m}$ depth, and specifically at an isotherm of around $25^{\circ} \mathrm{C}$, would be a better approach to determine the potential spawning areas for swordfish than surface temperature.

\footnotetext{
${ }^{1}$ U.S. Department of Commerce National Oceanic and Atmospheric Administration, <http://www.esrl.noaa.gov/psd/cgi-bin/ DataAccess.pl?DB_dataset=NODC+World+Ocean+Atlas+1998\&DB_variable=Ocean+Temperature,+data+distribution \&DB _statistic $=$ Number+of+Cells+Influencing+the+value+of+this+cell\&DB_tid=135DB_did=45\&DB_vid=889>
} 
The relatively greater thermal stability of the surface layers of the westernmost intertropical regions of the Atlantic, in terms of temperature and deeper thermocline, would account for the great prevalence of maturationreproduction processes in females observed in the western oceanic zones and mainly in regions 07 and 08 all year round.

It has been pointed out that some exceptional reproductive events may be possible in July off the Azores (Simoes 2001) although the gonadal indices described generally confirm the absence of reproductive activity all year round. Similarly, some individuals with relatively high gonadal indices have been reported from regions of the NE Atlantic very near the Strait of Gibraltar (De la Serna et al. 1992) despite the fact that the mean values are regularly low and might even pertain to fishes of Mediterranean origin.

The CPUE data by sex-regions suggest that the CPUEs of females in regions 07 and 08 do not differ substantially from the regions in close proximity, although differences were found in relation to the regions located far from the temperate areas. In contrast, the CPUEs of males in regions 07 and 08 increase substantially in the regions closest to them, although with values similar to those found in more distant areas. However, a comparison of the CPUEs between regions did not provide a suitable interpretation of the data, particularly when comparing distant regions, since differences may arise in abundance or catchability among regions. Therefore, a comparison of the ratios between sexes (R_CPUE) among regions would appear to be a better approach to explain possible sex-segregation processes associated with the reproduction of this species.

The difference in the gonadal stages are quite easy to identify in the areas where maturation processes develop (as suggested in regions 07, 08 and 13) even for inexperienced observers. Despite its subjective nature, it was possible to identify the regions according to the reproductive processes observed in the gonadal stages, providing a quick and easy proxy that might be of some use in defining the developmental stage of female gonads and the areas where maturation-reproduction could take place, for lack of a better alternative. However, this qualitative method is probably less effective in accurately delimiting the regions since it is highly dependent upon the criteria and experience of the observer and well standardized criteria among observers.
The results obtained support the highest reproductive processes observed in regions 07,08 and 13 associated with warm waters and the highest prevalence of males within a particular size range. The maturation-spawning regions support structured swordfish populations as has been postulated in studies on sex-ratio at size (Mejuto et al. 1998, Mejuto 2007), also corroborated by studies on the genetic similarity between regions (Alvarado-Bremer et al. 2005) and assumed by ICCAT (Neilson et al. 2013). The reproductive behavior of this species is therefore much more complex than previously thought. Elements such as external stimuli of attraction and courting behavior in the spawning zones should be considered, in keeping with the descriptions of the Galician fishermen who have dubbed these zones 'o mar dos namorados' (the sea of lovers), alluding to the areas of observed courting activity between genders, that have eluded scientific explanation.

The swordfish stocks under the purview of ICCAT have been subject to a successful recovery plan (Anonymous 2013). However, stock assessments have been limited by some uncertainties, including the reproductive parameters and doubts regarding the stock structure assumed (Neilson et al. 2013). The results achieved by this research contribute to gain insight into the biology and the reproductive behavior of this species, thereby reducing those uncertainties, as the study covers a substantial part of the oceanic area where swordfish is mainly distributed in the Atlantic. Combining the knowledge on reproduction and other sources of information such as genetic studies, horizontal and vertical migrations, mixing among regions, etc., a plausible stock structure for this cosmopolitan and highly-migratory species it could be proposed. It is desirable to achieve as much harmonization as possible between 'biological stock' and 'management stock' in order to reduce the uncertainty in assessments and to improve the efficiency of the management actions trying to keeping stocks within sustainable exploitation levels. Likewise, knowing the biological structure in each stock and the biological processes developed in each region is the key to develop more realistic and species-adapted models and to propose management scenarios for specific areas when these are necessary for stock sustainability. In addition, the obtained results help to focus future research based on microscopic techniques, giving priority to those areas where the reproductive processes have been evidenced. 


\section{ACKNOWLEDGMENTS}

The authors would like to thank the crews of the Spanish surface longliners for their continuing collaboration and for allowing scientific observers to board their vessels. Professor Victoriano Urgorri improved the papers with interesting suggestions. Professor Jaime Gómez-Márquez encouraged us to summarize this experience. We want to pay special tribute to Ana Ramos-Cartelle for her invaluable help with the figures and the adjustment to the required formats. Special thanks go out to the scientific observers and assistants for their efforts in providing quality work, as well as to the referees for the helpful reviews of the manuscript.

\section{LITERATURE CITED}

Alvarado-Bremer JR, J Mejuto, J Gómez-Márquez, F Bona, P Carpintero, JM Rodríguez, J Viñas, TW Grieig \& B Ely. 2005. Hierarchical analyses of genetic variation of samples from breeding and feeding grounds confirm the genetic partitioning of northwest Atlantic and South Atlantic populations of swordfish (Xiphias gladius L.). Journal of Experimental Marine Biology and Ecology 327: 167-182.

Amorin AF \& CA Arfelli. 1984. Estudo biológico-pesquero do espadarte, Xiphias gladius Linnaeus, 1758, no Sudeste e Sul do Brasil (1971-1981). Boletim Instituto da Pesca, Sao Paulo 11: 35-62.

Anonymous. 2000. Detailed report on swordfish: Report of the ICCAT swordfish assessment session (Madrid, Spain, September 27-October 4, 1999). ICCAT, Collective Volume of Scientific Papers 51(4): 1001-1208.

Anonymous. 2013. Report of the 2013 Atlantic swordfish stock assessment session (Olhao, Portugal, September 210, 2013). ICCAT, SCI-036/2013: 1-132.

Aranda G, A Medina, A Santos, FJ Abascal \& T Galaz. 2013. Evaluation of the Atlantic bluefin tuna reproductive potential in the western Mediterranean Sea. Journal of Sea Research 76: 154-160.

Arocha F. 1997. The reproductive dynamics of swordfish Xiphias gladius L. and management implications in the Northwestern Atlantic. A dissertation submitted to University of Miami for degree of Doctor of Philosophy, Coral Gables, Florida, 115 pp.

Arocha F. 2002. Oocyte development and maturity classification of swordfish from the north-western Atlantic. Journal of Fish Biology 60: 13-27.

Arocha F. 2007. Swordfish reproduction in the Atlantic Ocean: an overview. Gulf and Caribbean Research 19(2): 21-36.

Arocha F \& DW Lee. 1995. The spawning of swordfish in the Northwest Atlantic. ICCAT, Collective Volume of Scientific Papers 44(3): 179-186.
Arocha F \& DW Lee. 1996. Maturity at size, reproductive seasonality, spawning frequency, fecundity and sex ratio in swordfish from the Northwest Atlantic. ICCAT, Collective Volume of Scientific Papers 45(2): 350-357.

Arocha F, DW Lee \& JR Grubich. 1994. Observations on sex ratio, maturity stages, and fecundity estimates of the swordfish, Xiphias gladius, in the Northwest Atlantic Ocean. ICCAT, Collective Volume of Scientific Papers 42(1): 309318.

Becket JS. 1974. Biology of swordfish, Xiphias gladius L., in the Northwest Atlantic Ocean. Proceeding of the International Billfish Symposium, Kailua-Kona, Hawaii, 9-12 August 1972. NOAA Technical Report, NMFS SSRF675 Part 2: 103-106.

Cayre P \& F Laloe. 1986. Review of the Gonad Index (GI) and introduction to the concept of its 'critical value': application to the skipjack tuna Katsuwonus pelamis in the Atlantic Ocean. Marine Biology 90: 345-351.

De la Serna JM, E Alot \& MD Godoy. 1992. Análisis preliminar de la madurez sexual del pez espada (Xiphias gladius) en el área Atlántica próximas al estrecho de Gibraltar. ICCAT, Collective Volume of Scientific Papers 29(2): 522-537.

De la Serna JM, JM Ortiz \& D Macias. 1996. Observations on sex-ratio, maturity and fecundity by length-class for swordfish (Xiphias gladius) captured with surface longline in the western Mediterranean. ICCAT, Collective Volume of Scientific Papers 45(1): 115-140.

DeMartini EE. 1999. Size-at-maturity and related reproductive biology. US Department of Commerce, NOAA Technical Memorandum NMFS, NOAA-TM-NMFS-SWFSC-263: 161-169.

DeMartini EE, JH Uchiyama \& HA Willians. 2000. Sexual maturity, sex ratio, and size composition of swordfish, Xiphias gladius, caught by the Hawaii-based pelagic longline fishery. Fishery Bulletin 98: 489-506.

Demetrio G, P Magalofonou, S Tselas \& N Tsimenides. 1989. Fishery and biology of the swordfish, Xiphias gladius, L., 1758, in Greek waters. FAO Fisheries Report 412: 135-145.

Esteves E, P Simoes, HM Da Silva \& JP Andrade. 1995. Ageing of swordfish, Xiphias gladius Linnaeus 1758, from de Azores, using sagittae, anal-fin spines and vertebrae. Arquipelago. Life and Marine Sciences 13A: 39-51.

García B \& J Mejuto. 1988. Primeros datos sobre la biología de la reproducción del pez espada (Xiphias gladius L.) de las áreas $35^{\circ}-45^{\circ} \mathrm{N}, 10^{\circ}-40^{\circ} \mathrm{W}$ (BIL-94). ICCAT, Collective Volume of Scientific Papers 27: 164-177.

García-Cortés B \& J Mejuto. 2003. Sex ratio patterns and gonadal indices of the swordfish (Xiphias gladius) caught by the Spanish surface longline fleet in the Indian Ocean. IOTC WPB-2003-04, Proceedings 6: 287-299.

Goode GB. 1883. Materials for a history of the sword-fishes. In: U.S. Commission of Fish and Fisheries, Report of the Commissioner for 1880, Part 8: 290-394. 
Govoni JJ, BW Stender \& O Pashuk. 2000. Distribution of larval swordfish Xiphias gladius, and probable spawning off Southern United States. Fishery Bulletin 98: 64-74.

Guitart-Manday D. 1964. Biología pesquera del emperador o pez espada, Xiphias gladius Linnaeus (Teleostomi: Xiphiidae) en las aguas de Cuba. Poeyana, Series B 1: 1-37.

Hazin F, H Hazin, C Boeckmenn \& P Travassos. 2001. La reproduction de l'espadon (Xiphias gladius) dans l' Atlantique sud-ouest equatorial: la ponte et la fecondite. ICCAT, Collective Volume of Scientific Papers 52: 12331240.

Hinton MG, RG Taylor \& MD Murphy. 1997. Use of gonad indices to estimate the status of reproductive activity of female swordfish, Xiphias gladius: a validated classification method. Fishery Bulletin 95: 80-84.

Kume S \& J Joseph. 1969. Size composition and sexual maturity of billfishes caught by the Japanese longline fishery in the eastern Pacific Ocean east of $130^{\circ}$ W. Far Seas Fisheries Research Laboratory Bulletin 2: 115-162.

MathSoft. 1997. S-PLUS 4: Guide to Statistics, 877 pp. Data Analysis Products Division, MathSoft, Seattle.

Matsumoto WM \& TK Kazama. 1974. Occurrence of young billfishes in the Central Pacific Ocean. In: Shomura RS \& F Williams (eds). Proceedings of the International Billfish Symposium, Kailua-Kona, Hawaii, August 9-12, 1972. Part 2. Review and Contributed Papers, US Department of Commerce. NOAA Technical Report. NMFS-SSRF-675: 238-251.

Mejuto J. 1999. A possible relationship between the NAO index and the swordfish (Xiphias gladius) recruitment index in the North Atlantic: Hypothesis of reproduction and possible effects on recruitment levels. ICCAT, Collective Volume of Scientific Papers 69(4): 339-345.

Mejuto J. 2007. Aspectos biológicos y pesqueros del pez espada (Xiphias gladius Linnaeus, 1758) del océano Atlántico, con especial referencia a las áreas de actividad de la flota española. Tesis doctoral, Universidade de Santiago de Compostela, Galicia, 224 pp.

Mejuto J \& B García-Cortés. 1997. A preliminary analysis of the gonadal indices of the swordfish (Xiphias gladius, L.) in the Atlantic Ocean. ICCAT, Collective Volume of Scientific Papers 46(3): 336-344.

Mejuto J \& B García-Cortés. 2003a. Size segregation, sex ratios patterns of the swordfish (Xiphias gladius) caught by the Spanish surface longline fleet in areas out of the Atlantic ocean and methodological discussion on gonadal indices. ICCAT, Collective Volume of Scientific Papers 55(4): 1459-1475.

Mejuto J \& B García-Cortés. 2003b. Adescription of possible spawning areas of the swordfish (Xiphias gladius) in the tropical northwest Atlantic. ICCAT, Collective Volume of Scientific Papers 55(4): 1449-1458.
Mejuto J \& JJ Hoey. 1991. An approach to a stock hypothesis for the swordfish (Xiphias gladius) of the Atlantic Ocean. ICCAT, Collective Volume of Scientific Papers 35(2): 482501.

Mejuto J, JM De la Serna, B García, M Quintans \& E Alot. 1994. Sex ratio at size of the swordfish (Xiphias gladius L.) in the Atlantic and Mediterranean Sea: Similarity between different spatial-temporal strata. ICCAT, Collective Volume of Scientific Papers 42(1): 322-327.

Mejuto J, JM De la Serna \& B García. 1995. An overview of the sex-ratio at size of the swordfish (Xiphias gladius L.) around the world: Similarity between different strata. ICCAT, Collective Volume of Scientific Papers 44(3): 197-205.

Mejuto J, JM De la Serna \& B García. 1998. Some considerations on the spatial and temporal variability in the sex-ratio at size of the swordfish (Xiphias gladius). ICCAT, Collective Volume of Scientific Papers 48(1): 205-215.

Mejuto J, B García-Cortés \& A Ramos-Cartelle. 2006. An overview of research activities on swordfish (Xiphias gladius) and the by-catch species, caught by the Spanish longline fleet in the Indian Ocean. IOTC Working Party on Billfish 2006, WPB-2006-11: 1-23.

Mejuto J, B García-Cortés \& A Ramos-Cartelle. 2008. Reproductive activity of swordfish (Xiphias gladius) in the Pacific Ocean on the basis of different macroscopic indicators. $4^{\text {th }}$ Regular Session of the Scientific Committee of the WCPFC, BI-2008 / WP 06: 1-23.

Miyabe N \& WH Bayliff. 1987. A review of the Japanese longline fishery for tunas and billfishes in the eastern Pacific Ocean, 1971-1980. IATTC Bulletin 9(1): 1-163.

Miyake M. 1990. Manual de operaciones para las estadísticas y el muestreo de túnidos y especies afines en el océano Atlántico, 188 pp. Comisión Internacional para la Conservación del Atún Atlántico (ICCAT), Madrid.

Nakano H \& WH Bayliff. 1992. A review of the Japanese longline fishery for tunas and billfishes in the eastern Pacific Ocean, 1981-1987. IATTC Bulletin 20(5): 183-155.

Neilson J, F Arocha, S Cass-Calay, J Mejuto, M Ortiz, G Scott, C Smith, P Travassos, G Tserpes \& I Andrushchenko. 2013. The Recovery of Atlantic Swordfish: The Comparative Roles of the Regional Fisheries Management Organization and Species Biology. Reviews in Fisheries Science 21(2): 59-97.

Nishikawa Y \& S Ueyanagi. 1974. The distribution of the larvae of swordfish, Xiphias gladius, in the Indian and Pacific Oceans. U.S. Department of Commerce, NOAA Technical Report, NMFS, SSRF-675: 261-264.

Nishikawa Y, S Kikkawa, M Honma \& S Ueyanagi. 1978. Distribution atlas of larval tunas, billfishes, and related species-results of larval surveys by R/V Shunyo Maru and Shoyo Maru (1956-1975). Far Seas Research Laboratory, S Series 9: 1-99. 
Nishikawa Y, M Honma, S Ueyanagi \& S Kikkawa. 1985. Average distribution of larvae of oceanic species of scombroid fishes, 1956-1981. Far Seas Fisheries Research Laboratory, S Series 12: 1-99.

Palko BJ, GL Beardsley \& WJ Richards. 1981. Synopsis of the biology of Swordfish, Xiphias gladius Linnaeus. FAO Fisheries Synopsis 127: 1-21.

Poisson F \& C Fauvel. 2009a. Reproductive dynamics of Swordfish (Xiphias gladius) in the Southwestern Indian Ocean (Reunion Island). Part 1: oocyte development, sexual maturity and spawning. Aquatic Living Resources 22: 4558.

Poisson F \& C Fauvel. 2009b. Reproductive dynamics of Swordfish (Xiphias gladius) in the Southwestern Indian Ocean (Reunion Island). Part 2: fecundity and spawning pattern. Aquatic Living Resources 22: 59-68.

Poisson F \& M Taquet. 2000. French swordfish longline fishery in South West Indian Ocean: preliminary results from the PPR Program. IOTC Proceedings 3, WPB-00-06: 169-201.

Poisson F, C Marjolet \& C Fauvel. 2001. Sexual maturity, spawning season and estimation of batch fecundity of Swordfish (Xiphias gladius) caught by the Reunion-based pelagic longline fishery (SWOI). IOTC Proceedings 4, WPB01-05: 120-125.

Ramon D \& R Castro-Longoria. 1994. Sex composition and maturity of swordfish, Xiphias gladius, caught in the driftnet fishery along the coast of California and Oregon, 1990-1993 and Baja California, 1992-1993. (Abstr.) First International Swordfish Symposium, Ensenada, Baja California, Mexico, pp. 11-14.

Rey JC. 1988. Comentarios sobre las áreas de reproducción del pez espada, Xiphias gladius, en el Atlántico y Mediterráneo. ICCAT, Collective Volume of Scientific Papers 27: 180-193.
Simoes P. 2001. Aspectos da biologia e da pesca da espadarte (Xiphias gladius L. 1758), no arquipélago dos Açores. Dissertaçao Doutor em Ciencias Biológicas e Tecnología das Pescas, Especialidade de Pescas, Universidade do Algarve, Faro, 357 pp.

Sparre P \& SC Venema. 1997. Introducción a la evaluación de los recursos pesqueros. Part 1: Manual. FAO Technical Report 306/1 Rev.2: 1-420.

Taylor RG \& MD Murphy. 1992. Reproductive biology of the swordfish Xiphias gladius in the Straits of Florida and adjacent waters. Fishery Bulletin 90(4): 809-816.

Turner SC, VR Restrepo \& F A rocha. 1997. Swordfish catch at size and catch at age by sex for the United States. ICCAT, Collective Volume of Scientific Papers 46(3): 383-385.

Varghese SP, K Vijayakumaran, A Anrose \& VD Mhatre. 2013. Biological aspects of swordfish, Xiphias gladius Linnaeus, 1758, caught during tuna longline survey in the Indian seas. Turkish Journal of Fisheries and Aquatic Sciences 13: 529-540.

Weber EC \& SR Goldberg. 1986. The sex ratio and gonad indices of swordfish, Xiphias gladius, caught off the coast of Southern California in 1978. Fishery Bulletin 84: 185186.

West G. 1990. Methods of assessing ovarian development in fish: a review. Australian Journal of Marine and Freshwater Research 41: 199-222.

Young J, A Drake, M Brickhill, J Farley \& T Carter. 2003. Reproductive dynamics of broadbill swordfish, Xiphias gladius, in the domestic longline fishery off eastern Australia. Marine and Freshwater Research 54: 315-332.

Yuen HSH. 1955. Maturity and fecundity of bigeye tuna in the Pacific. In: U.S. Department of the Interior, Fish and Wildlife Service, Washington. Special Scientific Report, Fisheries 150: 1-30. 